\title{
Early Modern Ottoman Coffeehouse Culture and the Formation of the Consumer Subject
} Author(s): Emİnegül Karababa and Gülİz Ger

Source: Journal of Consumer Research, Vol. 37, No. 5 (February 2011), pp. 737-760

Published by: Oxford University Press

Stable URL: http://www.jstor.org/stable/10.1086/656422

Accessed: 29-08-2017 12:39 UTC

JSTOR is a not-for-profit service that helps scholars, researchers, and students discover, use, and build upon a wide range of content in a trusted digital archive. We use information technology and tools to increase productivity and facilitate new forms of scholarship. For more information about JSTOR, please contact support@jstor.org.

Your use of the JSTOR archive indicates your acceptance of the Terms \& Conditions of Use, available at http://about.jstor.org/terms 


\title{
Early Modern Ottoman Coffeehouse Culture and the Formation of the Consumer Subject
}

\author{
EMINEGÜL KARABABA \\ GÜLIZ GER
}

\begin{abstract}
We examine the sociohistorical formation of the consumer subject during the development of consumer culture in the context of leisure consumption. Specifically, we investigate how an active consumer was forming while a coffeehouse culture was taking shape during early modern Ottoman society. Utilizing multiple historical data sources and analysis techniques, we focus on the discursive negotiations and the practices of the consumers, the marketers, the state, and the religious institution as relevant stakeholders. Our findings demonstrate that multiparty resistance, enacted by consumers and marketers, first challenged the authority of the state and religion and then changed them. Simultaneously and at interplay with various institutional transformations, a public sphere, a coffeehouse culture, and a consumer subject constructing his self-ethics were developed, normalized, and legalized. We discuss the implications of the centrality of transgressive hedonism in this process, as well as the existence of an active consumer in an early modern context.
\end{abstract}

$\mathrm{P}$ leasure and leisure are two important characteristics of today's consumer culture (Belk, Ger, and Askegaard 2003; Goulding et al. 2009; Hirschman and Holbrook 1982; Kozinets et al. 2004; Urry 2000). Masses of consumers enjoy leisure away from home and work in "third places" such as cafés (Kjeldgaard and Ostberg 2007; Oldenburg 1999; Thompson and Arsel 2004). Today we are surrounded by many cafés in various styles. Some are global-branded like Starbucks (Ritzer 2007). Some are local, defined either by anticorporate discourses (Thompson and Arsel 2004) or by hybridization of multiple local traditional and global forms (Kjeldgaard and Ostberg 2007). Today's café culture has materialized with certain continuities and ruptures from its origins. Kjeldgaard and Ostberg challenge the global-local di-

Emınegül Karababa (e.karababa@exeter.ac.uk) is lecturer in marketing, University of Exeter, Exeter, EX4 4PU, UK. Güliz Ger (ger@bilkent.edu.tr) is professor of marketing, Bilkent University, Ankara, 06800, Turkey. The authors would like to thank Halil İnalcık and Mehmet Kalpaklı for sharing their invaluable knowledge and sources and Jonathan Schroeder for his useful comments on earlier versions of this article. The authors are grateful for the supportive and helpful remarks and insights provided by the editor, the associate editor, and the reviewers, particularly the trainee reviewer.

John Deighton served as editor and Russell Belk served as associate editor for this article.

Electronically published August 31, 2010 chotomy and argue that neither global nor local coffee shops are authentic but rather are both globally and sociohistorically formed, stemming from seventeenth-century European coffeehouses. The earliest form of the coffeehouse emerged in the mid-sixteenth-century Ottoman Empire and spread to the world in the next century. We investigate the sociohistorical construction of the initial form of this sphere and its consumers.

The coffeehouse, being a site of pleasurable leisure linked to both the birth of consumer culture and the less frivolous public sphere, is a significant entity. Commercialization and democratization of leisure-in coffeehouses, theaters, art galleries, concert halls, and gardens - in eighteenth-century England is one of the markers of the development of consumer culture (Plumb 1982). Similarly, the increased popularity of the Ottoman coffeehouse in the sixteenth and seventeenth centuries, revealing its commercialization and democratization, indicates an Ottoman consumer culture. It seems that the British coffeehouse, deemed to have founded the seventeenth-century public sphere (Habermas 1992), had its origins in Ottoman early modernity (Kömeçoğlu 2005; MacLean 2007; Öztürk 2005). In this study, we address the emergence of this significant site and its consumer in the unexpected Ottoman context rather than in an early modern Western context - the usual home of modernity and modern consumer culture.

In examining today's consumer culture, consumption studies 
generally portray consumers as subjects who actively negotiate and transform market-mediated meanings to define and express their identities and social relations (Arnould and Thompson 2005; Firat and Dholakia 1998; Firat and Venkatesh 1995; Slater 1997). Researchers often attribute this active self-definition to the transformation from a modern to a postmodern condition, where structural divisions like class and gender lose their importance in ascribing identities, and, instead, marketing and media make available numerous symbolic resources to the consumers for use in constructing their identities themselves (Frrat and Venkatesh 1995; Holt 1998; Slater 1997). Researchers have investigated the self-constituting consumer in a variety of contemporary contexts (Brown, Kozinets, and Sherry 2003; Holt and Thompson 2004; Kozinets et al. 2004; Maclaran and Brown 2005; Peñaloza and Gilly 1999; Thompson 2004; Thompson and Arsel 2004; Thompson and Haytko 1997). However, as Borgerson (2005) also argues, the theoretical underpinnings of the concept of the actively self-identifying consumer have not sufficiently been interrogated. That is, more research is needed on the conceptualization of the consumer and the context in which such a subject is formed in order to better understand the relationship between consumer subjects and their environments. In this research, our goal is to (re)examine the active consumer, who has usually been assumed to be the product of twentieth-century capitalism. By going back to an early modern period, we aim to explain how and under what conditions an active consumer subject was formed.

Scholars have linked the historical development of consumer culture to tendencies such as circumvention of sumptuary laws; spread of consumer goods, luxury, fashion, and leisure time activities to masses; and interactions among various consumer cultures (Arvidsson 2003; Brewer and Porter 1993; De Vries 2008; McKendrick, Brewer, and Plumb 1982; Mukerji 1983; Roche 2000). However, this literature does not explain if and how the consumer subject was formed during the development of consumer culture (Poster 1989). Instead, it supposes a rather passive consuming subject (Firat and Dholakia 1998; McKendrick, Brewer, and Plumb 1982) shaped by numerous structural transformations. These transformations entail the emergence of a new class, the bourgeois between the aristocracy and peasantry (McKendrick et al. 1982; Mukerji 1983; Simmel 1957; Veblen 1899/1994), the growth of urbanization and commercialization (Braudel 1993; Polanyi 1957; Roche 2000; Schama 1987), the formation of new ethics (Campbell 1987; Mukerji 1983), the changes in the economic policies of the state from mercantilism toward liberalism (McKendrick 1982; Mukerji 1983), and the new role taken on by the market, supplementing, for example, religion and state, in determining received reality and truth (Agnew 1993; Slater 1997). Albeit such structural changes, we wonder, if consumer culture was in the forming, should not the active consumer also be in the forming? So we examine if and how a consumer subject was constructed during the development of a consumer culture and if and how the consumer interacted with structural formations. Interrogating the sup- posed unidirectional link from structure to consumer, we focus on the Ottoman coffeehouse consumer. We address the following question: How did early modern people, supposedly tied to prescriptions, move from such prescribed manners of consumption to negotiated and at least partially self-determined modes?

We focus on the sixteenth-century and seventeenth-century Ottoman era since this was the place and time of the emergence of the coffeehouse, which then spread to Europe. Upon its popularity, first in Istanbul and then elsewhere in the empire, Mediterranean merchants introduced coffee to Europe (De Lemps 1999) through the ports of Venice, Marseille, London, and Amsterdam (Schievelbusch 2000). Coffee reached Venice in 1615 (Braudel 1992). The first coffee shop was opened in London in 1652, followed by many others (Wills 1993). In France, in 1672, coffee was marketed with exotic Turkish images at stalls decorated with tapestries, mirrors, chandeliers, and preserved fruits (Ellis 2004). By the early eighteenth century, coffee was introduced to the Netherlands (Schama 1987), proliferating further the drink and its sites of leisure. The Ottoman Empire's role in the world was not limited to the spread of coffee and coffeehouses. As a then world power, it ruled the lands and trade routes in three continents-southeast Europe, the Middle East, and North Africa (Fisher 1971) — and contributed politically, economically, and culturally to its period, including the European renaissance (İnalc1k 1974; MacLean 2005). Consider depictions by painters Holbein, Bellini, and Lotto of Turkish carpets or Mozart's "Rondo Alla Turca," inspired by the Ottoman army band. Today, we have Dave Brubeck's "Blue Rondo a la Turk," Ottoman influence is still visible in its former lands, and its much less powerful successor, Turkey, is among the G20.

The sixteenth-century and seventeenth-century Ottoman society saw not only coffeehouses but also transformations in broader consumption patterns (Grehan 2007; Karababa 2006) and a decline in obedience to religious and legal prescriptions. Focusing on the coffeehouse, a precursor of the third place, and aiming to understand the formation of an active consumer and a coffeehouse culture, we examine the change in subjects-how they move from obeying prescriptions to rejecting them, or, from being sultan's subjects to becoming consumer subjects.

We adopt an anthropological-historical approach in order to understand the formation and social construction of an active, yet early modern, coffeehouse consumer in relation to market institutions - in this case, guilds as well as the state and the religious authority. Concurring with Peñaloza (2000), we examine marketplace interactions at the discursive and practice levels. At the practice level, we focus on the transgressions of the consumers, resistances of the guilds, enforcements of the state and the religious authority, and the changes in the discursive practices of these actors. At the discourse level, we examine the power struggles among countervailing discourses (Foucault 1980) to understand consumer resistances in the form of tactics (De Certeau 1988) and the ethical constitution (Foucault 2000) of 
TABLE 1

TYPES OF DATA SOURCES

\begin{tabular}{|c|c|c|c|}
\hline Name & Definition & Authorship & Purpose of usage \\
\hline Ottoman historiography & $\begin{array}{l}\text { Scholarly research on } \\
\text { history }\end{array}$ & - Contemporary historians & $\begin{array}{l}\text { - The Ottoman context } \\
\text { - Raw data and expert analysis of } \\
\text { poetry and other data }\end{array}$ \\
\hline Interviews & With Ottoman historians & $\begin{array}{l}\text { - Halil İnalcık } \\
\text { - Mehmet Kalpaklı }\end{array}$ & $\begin{array}{l}\text { - Locating data on consumer culture } \\
\text { and coffeehouses } \\
\text { - Suggestions and feedback on data } \\
\text { analysis }\end{array}$ \\
\hline Fatwas & $\begin{array}{l}\text { Opinion of religious } \\
\text { authority }\end{array}$ & $\begin{array}{l}\text { - Ebussuud Efendi } \\
\text { - Bostanzade }\end{array}$ & $\begin{array}{l}\text { - Discourses on the coffeehouse } \\
\text { - Changes in the norms }\end{array}$ \\
\hline Decrees & Sultan's order & & $\begin{array}{l}\text { - Discourses on the coffeehouse } \\
\text { - Practices of the state, consumers, and } \\
\text { coffeehouse owners }\end{array}$ \\
\hline Poems and tezkires & $\begin{array}{l}\text { Tezkire is similar to a } \\
\text { poetry anthology }\end{array}$ & $\begin{array}{l}\text { - Anonymous } \\
\text { - Various authors } \\
\text { - Tezkire: Aşık Çelebi (a judge) }\end{array}$ & $\begin{array}{l}\text { - Discourses on the coffeehouse } \\
\text { - Descriptions of coffeehouse objects, } \\
\text { design, service, and experiences } \\
\text { - Cultural production according to social } \\
\text { classes }\end{array}$ \\
\hline Festival books & $\begin{array}{l}\text { Accounts of festivals held } \\
\text { by the palace }\end{array}$ & $\begin{array}{l}\text { - Intizami (unknown biography) } \\
\text { - Gelibolu'lu Mustafa Âlî } \\
\text { (bureaucrat) }\end{array}$ & $\begin{array}{l}\text { - The coffeehouse context, events, } \\
\text { activities, consumer experiences } \\
\text { and reactions } \\
\text { - Relations among consumers from } \\
\text { different social classes }\end{array}$ \\
\hline Chronicles & $\begin{array}{l}\text { Accounts of historical } \\
\text { events }\end{array}$ & $\begin{array}{l}\text { - Peçevi Efendi } \\
\text { - Katip Çelebi } \\
\text { - Koçu Bey }\end{array}$ & $\begin{array}{l}\text { - Economic, social, and political } \\
\text { changes } \\
\text { - History of the coffeehouses }\end{array}$ \\
\hline Book on morality & $\begin{array}{l}\text { Account of Orthodox } \\
\text { Islamic morality }\end{array}$ & - Kınalızade Ali Efendi (scholar) & $\begin{array}{l}\text { - Appropriate ways of consumption } \\
\text { - Norms }\end{array}$ \\
\hline Etiquette books & Depictions of manners & $\begin{array}{l}\text { - Anonymous } \\
\text { - Gelibolu'lu Mustafa Âlî }\end{array}$ & $\begin{array}{l}\text { - Everyday life and appropriate manners } \\
\text { - Deviances from the norms } \\
\text { - Consumption experiences }\end{array}$ \\
\hline Travelers' notes & $\begin{array}{l}\text { Notes and letters of } \\
\text { Europeans }\end{array}$ & $\begin{array}{l}\text { - Schweigger } \\
\text { - Thévenot } \\
\text { - And others }\end{array}$ & $\begin{array}{l}\text { - Outsider's view on Ottoman culture } \\
\text { and everyday life }\end{array}$ \\
\hline Price book & Price lists for goods & - Issued by the state & $\begin{array}{l}\text { - Types, qualities, and prices of goods } \\
\text { in the market }\end{array}$ \\
\hline $\begin{array}{l}\text { Miniatures, engravings, } \\
\text { drawings }\end{array}$ & Visual depictions & $\begin{array}{l}\text { - Miniatures: Ottomans } \\
\text { - Engravings and drawings: by } \\
\text { European travelers }\end{array}$ & $\begin{array}{l}\text { - Depiction of coffeehouse objects, design, } \\
\text { service, and experiences } \\
\text { - Comparison with insider's views }\end{array}$ \\
\hline
\end{tabular}

the coffeehouse consumer. De Certeau's theory of practice complements Foucault's later analysis of the structures of power in that the individual's agency is enacted through the utilization of alternative meaning systems in the society. At both practice and discourse levels, and akin to Belk et al. (2003), we focus on the dialogic relationship between the pursuit of pleasure and religious morality. We delineate how these struggles composed an active consumer subject, the Ottoman coffeehouse culture, and a public sphere.

\section{METHOD}

Historical research necessitates much iteration among data sources and literature throughout the research process (Smith and Lux 1993) as well as comparison and contrasting of different sources (Jenkins 2003). Accordingly, we examined the literature on history of consumption and the early modern Ottoman context and interviewed eminent Ottoman historians about the topic and the data sources. We critically evaluated and compared the literatures on history of con- sumption and Ottoman history, considering various disparities in theoretical and scholarly perspectives as well as the contextual differences.

We were bound by the available data sources, as all historical researchers are (Tosh 2006). To be able to attain trustworthiness, we relied on diverse data sources and multiple analysis techniques. We sought sources to help us identify the coffeehouse context; discourses operating in the coffeehouse realm; practices of the consumers and the market actors; changes in these practices; and transformations in the demographic, social, cultural, economic, and political domains. In addition to the vast literature on Ottoman history, our data sources include decrees, two fatwas, two festival books, a tezkire (poetry anthology), various poems, two etiquette books, two chronicles, a morality book, various European travelers' notes, miniatures, engravings, and drawings (table 1), in other words, any and all available data. We scrutinized these sources depending on their official or nonofficial status. For example, if the author or the patron of a text was from the officialdom, we expected the text to 
represent or at least not oppose the official discourse. Decrees, fatwas, miniatures, chronicles, and books on prices, etiquette, morality, and festivals oftentimes reflect the official view. One of the etiquette books is a letayif, an Ottoman genre that criticizes everyday conduct (Çavuşoğlu 1977). The original work, likely to have been written in the sixteenth century, was reproduced by different writers until the nineteenth century (Esir 2001). Poetry can reflect official or nonofficial views, depending on the author's background. Some tezkires, such as Aşık Çelebi's, reflect both views, since they contain the authors' views about different poets and their everyday life conducts, as well as samples from their poems. Finally, European travelers' notes, engravings, and drawings represent outsiders' views.

Most of the data sources-except travelers' notes and visual sources - are in Ottoman Turkish, the language between the sixteenth and nineteenth centuries in the Ottoman Empire. Ottoman Turkish is a combination of Arabic, Persian, and Turkish vocabularies and grammars (Kurt 1996) and is written with the Arabic script. Most of the archival texts used in this research are extracted from sources that include copies of original texts, transcriptions in the Latin alphabet, and textual and/or literary analyses. In some cases, we also sought literary interpretations from cultural historians. In addition, the first author has knowledge of reading, transcribing, and interpreting archival data sources and expertise in the archives of sixteenth-century and seventeenthcentury Ottoman probate inventories (Karababa 2006). She attended doctoral classes on historical research methods and Ottoman paleography and history. When presenting the data here, we often used her translations in English and provided the page numbers in the original source.

Some Ottoman sources are in the form of prose, such as the decrees and price books; others are in verse, but most are in mixed form, such as the etiquette, tezkire, and festival books. The popularity of poetry then is perhaps akin to that of music and video clips today. Poetry writing and reading was, and still is, very popular in the geography. Accordingly, it has been used in anthropological analyses, for example, in contemporary Egypt (Abu-Lughod 1999). Andrews (1985) argues that Ottoman poets sought to artfully reflect shared views and that thus Ottoman poetry is a communal art form that confirms the values, vision, and worldview of the community. Even the "high" form, divan poetry, produced by literate people and thus supposed to reflect the "high" culture, had a broad audience (Andrews 1985). The use of a limited vocabulary and a reliance on some key terms and stable metaphors made poetry widely accessible. Furthermore, the poets themselves did not belong to a single elite group of scholars but had diverse backgrounds: many were bureaucrats, artisans, and janissaries (members of the elite army of the Ottoman Empire; Hamadeh 2008; Kılıç 1994). İsen's (1989) study of the occupational backgrounds of a sample of 3,182 Ottoman poets indicates that $36 \%$ were scholars of theology, $28 \%$ bureaucrats, $5.7 \%$ sheikhs and dervishes, $3.7 \%$ military, $3.7 \%$ artisans and merchants, $1.8 \%$ courtiers, and $0.8 \%$ religious functionaries. Thus, these poems express shared values as well as a broad range of lives and experiences.

Our visual data sources included miniatures, engravings, and drawings that depict Ottoman coffeehouses from the late sixteenth century on. We present only one here: the miniature in figure 1 , since it provides the earliest and a highly detailed portrayal of the people and events in a coffeehouse. Interestingly, contrary to the premise that representational imagery was forbidden in Islamic cultures, various types of such imagery, as in miniatures, puppet theaters, figurative calligraphy, and figurative depictions on carpets, ceramics, copperware, and walls, were common and widely available to the Ottoman public (And 2004).

Throughout the analysis, we interrogated different paradigmatic stances that provided us with different levels of understanding. The first author engaged in a critical documentarist approach to make sense of what a particular document might have meant at the time it was produced (Carr 2001). Next, we studied the relations between consumption and demographic, economic, and social structures in the Annales tradition (Braudel 1980) to attain a macroscopic view. However, we do not subscribe to the Annales école assumption that changes in socioeconomic and demographic structures determine historical transformations in culture and human practices. Equipped with documentarist and macroscopic perspectives, we focused on the interplay between structure and the consumer subject. Such a poststructuralist approach (Jenkins 2003) is a recent cultural turn in the field of history and has been termed "cultural history" (Bonnell and Hunt 1999; Darnton 2001).

While we, like Campbell (1987), examine the formation of consumer and consumer culture, our poststructuralist perspective - as well as time periods and geographies-distinguishes our work from his. Focusing on eighteenth-century and nineteenth-century England, Campbell explains how the self-identifying consumer of the Enlightenment era was shaped by the Romantic ethic and accentuates the role of the structure-a new ethic. Instead of accepting the consumer as a construction of a specific ethics, we examine the consumer's role in shaping consumer culture and institutional practices; that is, we focus on the interplay between structural forms and consumers.

Furthermore, we conducted textual analysis, discourse analysis, and visual analysis. We analyzed verbal and visual data critically by considering the background of the author, the audience of the text, and the cultural context in which the text was produced (Baxandall 1988; Stern 1989). We examined how these texts are structured; the sequence of events; and the author's arguments, rationales, and justifications (Coffey and Atkinson 1996). In addition, we identified systems of statements and searched for repetitions in these statements to identify discourses (Foucault 1972/1998; Kendall and Wickham 2003). Then, we examined the data set to find discursive constructions of the use and meaning of the space, norms, and practices of consumers and institutions. In addition, we searched for discontinuities in dis- 
FIGURE 1

MINIATURE DEPICTING A LATE SIXTEENTH-CENTURY OTTOMAN COFFEEHOUSE

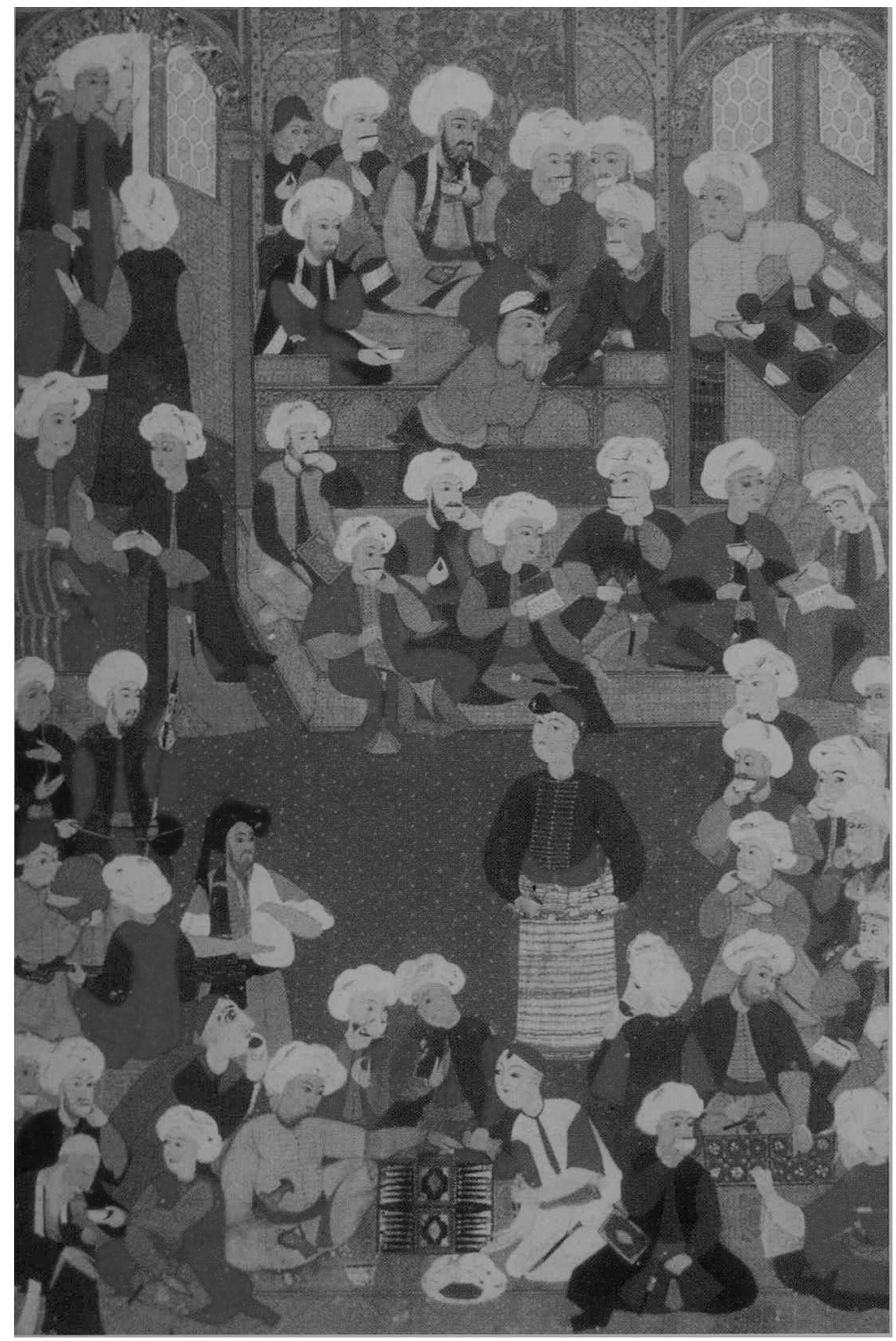

NOTE.-Produced by an anonymous artist. Miniature is held in the Chester Beatty Library, Dublin, no. 439.

cursive practices in order to discover the formation of a new consumer subject and institutional transformations.

While analyzing the visuals, we described, compared, and interpreted the people, the objects, and the activities depicted (Schroeder 2006). For example, the 45 men in the miniature in figure 1 were analyzed according to their appearances, locations, and social interactions. The flowers attached on their turbans represent a fashion of the era; different clothing styles represent various occupations.
Coffeehouse objects-blue-white Chinese cups, red carpets, and popular games like chess or mankala-represent the importance of aesthetics, pleasure, and comforts. Activities like performances and gambling reveal how leisure time was being enjoyed. The design and the use of different spaces by different types of people are also very telling: for example, the regulars were seated in a spacious section, close to the furnace. We also compared the visuals with textual data to help develop a particular in- 
terpretation. For instance, despite their different social positions, the learned, the dancers, and the dervishes interact in the coffeehouse: we see a dervish, denoted by his yellow felt canonical cap, discussing poetry with the turbaned poetry enthusiasts.

Miniatures were usually painted by palace artists as book illustrations or as single depictions, which were collected in albums (And 2004). They depicted special events as well as everyday lives. Depiction of everyday life was one of the novel styles becoming popular during the era and was also done by "bazaar painters" (And 2004). We compared Ottoman miniatures, representing perhaps an insider's view (Erzen 2002) with Western travelers' engravings and drawings of coffeehouses. At the simplest, the placement of the fountains at the vanishing point, which, in engravings, is regarded to represent the gaze of the artist or the audience (Panofsky 1993), signals the salience of al fresco enjoyment for the Western gaze. Thus, we examined data sources critically, comparatively, and iteratively and engaged in repeated discussions with eminent historians until the following account crystallized.

We present our findings in four sections. First, we demonstrate the presence of the early modern Ottoman consumer culture. Next, we provide an account of the coffeehouse culture, along with hedonistic, playful, and rebellious consumer practices. We propose that coffeehouse discussions, satirical performances, and humorous criticisms contributed to the formation of an early modern public sphere. The third section portrays the four discourses that frame coffeehouse culture and consumption. Finally, we explicate the formation of the coffeehouse culture and the consumer subject embedded in this early modern Ottoman consumer culture, its coffeehouse culture, and its discourses.

\section{OTTOMAN CONSUMER CULTURE: SIXTEENTH AND SEVENTEENTH CENTURIES}

Ottoman consumption patterns changed during the sixteenth and seventeenth centuries (Grehan 2007; Karababa 2006). This era was marked by significant discontinuity (Faroqhi 1997a; Inalc1k 1977): urbanization and commercialization picked up speed (Fletcher 1985; Pamuk 1999); upward and downward mobility increased (Kunt 1983); an urban popular culture emerged (Kafadar 1994); and disparities in religious norms, which defined appropriate ways of consumption surfaced (Karababa 2006). Ottoman codes, laws, and legal institutions aimed to attain obedience and justice, the two ideals of this centralized power. Justice, ruling in such a way as to protect the sultan's subjects from the exploitation of the representatives of the authority and from illegal taxation, was deemed necessary to maintain obedience (İnalcık 1973). However, this era was also a time when the extreme authority of the interventionist Ottoman state on production (Ínalc1k 1969, 1973) and consumption (Zilfi 2004) began to yield, along with such underlying ideals.

During the sixteenth and seventeenth centuries, while pleasures of consumption were becoming available to the newly rich middling ranks in the West (Berry 1994; Brewer and Porter 1993; McKendrick et al. 1982; Mukerji 1983; Plumb 1982; Roche 2000; Schama 1987; Slater 1997), the joy of consuming comforts, novelties, luxuries, and leisuretime pursuits enlivened the everyday life of the Ottoman urbanite (Karababa 2006). Similar to its Western counterparts, the early modern origins of Ottoman consumer culture are marked by the circumvention of sumptuary laws; increase in the amount of possessions and purchases; interest in comforts rather than just necessities; spread of consumer goods, including luxury, populuxe, fashion, and leisure time activities, to the masses; and interactions among various consumer cultures.

\section{The Class Structure and Sumptuary Laws}

The Ottoman society was composed of two main classes: the ruling and the ruled. The ruling class worked for the state as administrators, bureaucrats, armed forces (janissaries), and professors at theological schools, and its members were exempt from taxes. The ruled class included merchants, artisans, and the peasantry. However, as the class structure became more fluid during this period, the boundaries between the ruling and the ruled blurred (Faroqhi 1997a; Inalcık 1988; Kunt 1983; Pamuk 1999). Social status was not defined by family lineage, and thus the ruling class was open to penetration from the lower echelons. For example, many peasants attained education and then official posts (Faroqhi 1997a; Inalckk 1988) or the children of the Christians in the Balkans, converted to Islam, were educated and later hired for such positions as janissaries or bureaucrats (Goffman 2004; Thévenot 1978). In addition to upward mobility, certain state practices sometimes led to downward intergenerational mobility: occasional confiscation of wealth, aimed at maintaining social order, prevented steady and full transfer of economic capital between generations (İnalcık 1969, 1997). Moreover, people undertook occupations across classes. For example, janissaries and high-level bureaucrats became merchants and used their political muscle to compete with the guilds (Kunt 1983). Such transitions created an urban sphere where people from diverse backgrounds met. Fluid lifetime trajectories, intergenerational mobility, and migration diminished the security of social positions: ascribed identities could no longer persist.

Given this fluid context, the state issued sumptuary laws to maintain social and economic order, prevent sinful conduct, and avoid waste (Quataert 1997; Zilfi 2004), akin to the ethical, social, and economic rationales of sumptuary laws in the West (Belk 1995). Rules regarding types of clothing and accessories attempted to distinguish different status positions, genders, and religions: for example, only high officials could wear certain types of silk (Şeker 1997), and yellow and black shoes were for Muslim and non-Muslim women, respectively (Gürtuna 1999). Islamic law prohibited drinking wine and men's consumption of gold objects (Altınay 1988; Düzdağ 1998). Sumptuary laws could also prohibit women from patronizing places where they might interact with men: for example, sixteenth-century decrees 
forbade women from going to cream shops and taking pleasure boats on the Bosphorus (Altınay 1988). Finally, the on-and-off-prohibition of coffeehouses, which we discuss below, was among these sumptuary laws. Coffeehouse consumption was declared to be wasteful and spending time with pleasurable activities to be contrary to the Islamic work ethic (Hattox 1996).

By the sixteenth century, such sumptuary laws were frequently circumvented (Abou-El-Haj 2005; İnalcık 1973; Zilfi 2004), as they also were in the West during the formation of the Western consumer culture (Belk 1995). Belk argues that evasion of sumptuary laws indicates a widespread use of consumer goods. Accordingly, a seventeenthcentury Ottoman scholar, Koçu Bey, complained about the peasantry wearing the clothing and accessories, such as precious weaponry, formerly symbolic of elite status (Abou-ElHaj 2005). Similarly, sib and diba, two very precious fabrics deemed suitable only for sultans and their sons by the period's etiquette books, did not appear at all in the sixteenth-century Bursa probate records but surfaced in the seventeenth-century ones (Karababa 2006). Consumers were not alone in circumventing laws: the producers thwarted the strict legislation on production standards and began to produce new styles and cheaper versions of luxury goods (Inalc1k 1973). These populuxe goods appear to have served the consumers who either were not allowed or could not afford to use luxury goods, and thus they expanded consumption to a broadened population.

While sumptuary laws were not always implemented, etiquette books attempted to establish proper manners of consumption, especially regarding leisure activities such as eating, drinking, and socializing (Şeker 1997). In the Ottoman society, it was perhaps through shaping taste, rather than solely enforcing laws, that social class distinctions were attempted to be upheld, akin to sixteenth-century and seventeenth-century China (Bourdieu 1989; Clunas 2004). Regardless of, or perhaps due to, the legal and etiquette rules, consumption of populuxe goods prevailed.

\section{Increases in Possessions, Purchases, and Comfort}

Increases in the extent of acquisitions perhaps provide a more direct evidence of the spread of consumption in urban areas. A study of consumption in Bursa demonstrates that not only the ruling class but also the ruled class members acquired greater numbers of consumer items in the midseventeenth century than in the sixteenth century (Karababa 2006). For example, seventeenth-century women owned statistically significantly more objects, including headwear (çenber, arakiye), underwear (don and gönlek, zıbun), robes, outerwear, and belts, than did sixteenth-century women. Men as well as women owned more garments at this time (Karababa 2006). Similarly, there was a statistically significant increase in the numbers of home possessions-home furnishing and textiles_-per individual over the period. Such expansion was observed for bed sheets, quilts, pillows, floor coverings (kilim, keçe, döşeme), curtains, wrappers, towels, and chests. Increases in the numbers of possessions were not limited to the elite: individuals from the ruled class also owned more items in the seventeenth century than their counterparts in the sixteenth century (Karababa 2006). Furthermore, compared to what they produced at home, Ottoman urbanites purchased more items in the marketplace during the period. For example, during the sixteenth and seventeenth centuries, in cities like Bursa and Istanbul, there were many shops selling home textiles, clothing, and readymade foods like kebab, cream, desserts, and pastries (Altınay 1988; Faroqhi 1997b; Kütükoğlu 1983). Similarly, as we discuss below, the market provided entertainment in sites such as coffeehouses as an alternative to homemade amusements.

The increase in the acquisition of home furnishings and textiles paralleled the changes in the size and design of Ottoman houses. Eldem (1984a, 1984b) investigated the architectural development of Ottoman houses over time and found significant changes during the seventeenth century. At this time, urban houses were expanded by incorporating additional spaces, such as enclosing open porches with windows. Eldem (1984a) also finds that such redesign added comfort in terms of ease of heating and maintenance. Both the expansion of the indoor living space and the improved climate control and protection connote a rising concern for comfort. Furthermore, the above-mentioned increases in furnishings such as pillows, quilts, and floor coverings also imply a heightened interest in comfort.

\section{Widespread Consumption of Fashion, Luxury, and Leisure-Time Pleasures}

The seventeenth century saw the sudden appearance of novel styles of clothing, such as loose trousers and tight jackets, gold or silver accessories, and hair ornaments (Karababa 2006). Analysis of the Bursa probate records reveals that such novel items became available to the members of the ruled class as well as the ruling class. Emergence of novelties and items of adornment indicate the advent of fashion; adoption of these items by people of both classes signifies the popularity of this fashion consumption. The observed spread of fashionable consumer goods throughout the society is consistent with the fluid social structure that allowed mobility among strata and interaction of people from different ranks.

One item of luxury that seems to have been a rage is ornamented kuşaks (belts), woven of pure silk thread (ibrişim) or gold or silver threads. These must have been used so widely and sumptuously that a religious declaration, fatwa, eventually pronounced the inappropriateness of kuşaks for the public and even for high officials (Düzdağ 1998). Bursa probate records reveal that people obeyed the religious rules and that wasteful, luxurious kuşaks were not consumed during the sixteenth century (Karababa 2006). However, a century later, according to the same database, $64 \%$ of the ruling and $46 \%$ of the ruled class women possessed silver-threaded kuşaks. Moreover, some ruling class women had kuşaks decorated further with gold or precious jewels. This extravagance was 
not limited to the ruling class but surfaced in the probate records of a subset of the ruled class as well: the urban women.

Another example of the spread of fashions and luxury was the flourishing consumption of flowers and floral motifs on decorative objects and textiles. Flowers were used in home, garden, and personal decoration, as seen on the turbans in figure 1. Expanding "transcultural commodity" networks linking Asian and European consumer cultures enabled Ottoman consumers to buy luxurious imported flowers and thus enjoy a fashionable aesthetic pleasure (Salzman 2000). Specific flowers and floral motifs became fashionable and were represented in a diverse array of media, including ceramic tiles, carpets, porcelains, embroideries, and gilding (Taylor 1993). For example, tulips entered the scene during the late sixteenth century and replaced carnations and roses, the popular flowers and motifs of the earlier years (Ayvazoğlu 1992; Salzman 2000). Tulips, like coffeehouses, later spread to Europe.

Moreover, the early modern Ottoman society saw the advent of cheaper versions of luxury goods, which also played a role in the formation of the Western consumer culture (Fairchilds 1993). A European traveler wrote that, except for the very poor, it was not possible to find an Ottoman woman who did not possess silk clothing (Schweigger 2004). The state issued a price book listing approximately 260 different kinds of fabrics, of which 128 were various types of silks (Kütükoğlu 1983). Hence, consumers must have had a wide range of choices among 128 different varieties and prices of silks. Both luxury fabrics and their cheaper varieties were available in the market for use in clothing and home furnishings.

Finally, leisure-time activities were also democratized and commercialized. Sites of leisure included bathhouses, taverns, boza (a fermented wheat drink) shops, cream shops, gardens, and coffeehouses, all of which became popular during the period (Altınay 1988; Karababa 2006). Whereas the most popular site of leisure for men was the coffeehouse, for women it was the bathhouse. European travelers of the era noted that Ottoman middle-class women went to public baths up to four times a week and that sometimes they spent the whole day there grooming, socializing, feasting, and entertaining (And 1993). Overall, increased commercialization across borders provided opportunity for consumption for the masses and moved the site of production of goods or entertainment from the home to the market.

\section{Interactions with Other Early Modern Consumer Cultures}

Batchelor (2006) argues that international trade of fashion goods, such as Chinese porcelains, created similar types of consumers across different early modern societies. As the sixteenth-century and seventeenth-century Ottoman Empire controlled a significant part of the global commodity networks (Faroqhi 2007), many consumption items and tastes were imported and exported. Porcelain was one of those: the Portuguese traded porcelains from China to Ottoman lands (Kütükoğlu 1983). In the seventeenth century, Ottomans also produced porcelain locally. The decorations of these local porcelains entailed a mixture of Chinese, Persian, and Islamic motifs (Carswell 1998). This demonstrates that, as in today's global world, interactions among early modern societies created hybrid forms and tastes for such forms.

Imports, at a variety of quality and price levels, and the pursuant local production of highly demanded imports made exotic luxury and populuxe available to a wide range of consumers. Ottomans imported Venetian fabrics and glassware; woolen kerseys from London and Carcassone (and their Dutch imitations); silk fabrics from Florence, Venice, and France; cotton clothes from India (and their Iranian imitations); and Iranian carpets (Faroqhi 2007). One such item, kemha (a kind of silk brocade) became exceedingly popular in the sixteenth century (Dalsar 1960). By the seventeenth century, various versions of kemha were being imported. To exploit this new generation of kemhas and to compete against their foreign counterparts, Bursian weavers replicated these imported varieties. So, the domestic kemha trade also flourished. The enormous variety of fabrics imported to the Ottoman market led to changes in consumer tastes in a manner that producers found impossible to control (Faroqhi 2002).

Certain Ottoman ports and trade cities were active hubs in the sixteenth-century and seventeenth-century trade, and they played a key role in the spread of goods from the East to the West (Faroqhi 1997a; Inalcık 1997). In the seventeenth century, indigo, perfume bottles, drugs, and shawls from Lahore, as well as Ottoman cotton, were sold to central Europe (Faroqhi 2007). Ottoman and Asian goods-such as indigo, raw silk and cotton, yarns, fabrics, quilts, carpets, drugs, currants, and oil-spread throughout the English middle-class families by emulation and entrepreneurial activity as well as trade (MacLean 2007). The Ottoman coffeehouse was among the things that traveled to early modern Europe (Ellis 2004). It has since been reconstructed in various cultures and become a global leisure site.

\section{OTTOMAN COFFEEHOUSE CULTURE IN THE SIXTEENTH AND SEVENTEENTH CENTURIES}

While its earliest examples appear in the records of Mecca and Cairo in the 1510s, the coffeehouse became popular after the Ottoman conquest of Arab lands, in particular after two entrepreneurs from Aleppo and Damascus launched two coffeehouses in Istanbul in the early 1550s (Cohen 2004; Hattox 1996). Soon coffeehouses spread all over Istanbul and even to small towns in Anatolia (Arendonk 2009; Faroqhi 1986). With urbanization (Erder and Faroqhi 1980) and commercialization (Pamuk 1999), the coffeehouses formed alternative sites for Ottoman Muslim men, who formerly spent most of their time in prescribed spaces such as work, in a mosque, and at home. 


\section{Coffeehouse as a "Fourth Place"}

The Ottoman coffeehouse resembles today's cafés and neighborhood pubs in enabling individuals to interact with others and enjoy time away from their responsibilities (Oldenburg 1999). This location shares certain characteristics with contemporary "third places": a neutral meeting ground and social leveling, the presence of the regulars, and a site of socialization and various pleasures. It provided a "fourth place" in contrast to work, home, and mosque or Sufi lodges. In the early modern period, mosques, Sufi lodges, and perhaps even churches shared most of the above-noted third place characteristics with probably some pleasurable activities, too, at the least enjoyable interaction with others.

Ottoman coffeehouse consumption was a ritualistic pursuit of leisure with specific artifacts, particular participant roles, an informal script, and an audience (Rook 1985). In addition to coffee itself, poems, books, and musical instruments; games like backgammon and chess; and utensils like coffee grinders, ewers, trays, and porcelain cups were objects that contributed to this enjoyable activity. Carpets, the furnace, and the carved niches on the walls displaying porcelain cups provided the decor. Coffeemakers, servants, performers, storytellers, and consumers all had specific qualities and roles. Servants were expected to be young, beautiful, sexually appealing, and well dressed (Hattox 1996). Coffeemakers prepared coffee with precise instructions, exact timing, and specific mixes of ingredients. Performers danced and played music. As with many other sites of leisure-such as Chinese teahouses or Ottoman bathhouses - the coffeehouse staged basic human practices and routines of daily life such as eating and drinking. And the audience, the consumers, enjoyed the pleasures the coffeehouse staged.

Ottoman coffeehouses were designed in such a way that regulars oftentimes were seated on a platform at the corner, next to the furnace, which was reached by two narrow fenced staircases, similar to the ones in mosques (Ünver 1963). Regulars sitting on a higher platform, separated from the rest of the customers, are seen at the top-right corner of figure 1 . The regulars were mostly the coffee addicts and the elderly with high social rank; the youngsters, especially those making too much noise or engaging in "inappropriate" behaviors, were not allowed to sit with them (Ünver 1963). Oldenburg (1999) suggests that the regulars were the ones who created the friendly, warm, and unique atmosphere that made people feel at home.

The sixteenth-century and seventeenth-century coffeehouse was a "leveler," allowing people from different ranks to meet (Oldenburg 1999), akin to the early twentieth-century teahouses in China (Wang 2000). The French traveler Thévenot (1978) observed that everyone went to coffeehouses without facing discrimination based on occupation, religion, or status. Similarly, a decree issued in the sixteenth century informs us that men-of-letters, unemployed officers, judges, preachers, professors, university students, dervishes, merchants, military people, artisans, and poor and idle people all met there (Dağlioğlu 1940). Furthermore, the cof- feehouse offered a "neutral ground" (Oldenburg 1999) for social gatherings, in contrast to the host-guest relationship at homes. Peçevi's chronicle notes that at least the men-ofletters preferred the easier and cheaper coffeehouses over homes as meeting places (Baykal 1981).

Rather than merely providing a place to drink coffee, the coffeehouse created a pleasant site for patrons to interact in. It provided sociopleasure, enjoyment people share when they get together (Tiger 2005), to Ottoman urbanites, more of whom were becoming alienated from their roots and original communities with growing urbanization. Coffeehouse consumers enjoyed chatting, sharing news and rumors about the administration, and having literary conversations where writers submitted their latest compositions for assessment (Baykal 1981; Hattox 1996; Şeker 1997). A seventeenth-century poem demonstrates this ultimate goal of sociopleasure (Kafadar 2007, 120):

\section{The heart fancies neither coffee nor coffeehouse The heart fancies companionship [or conversation], coffee is an excuse.}

Companionship and socializing in the coffeehouse entailed play with autotelic and interpersonal actions (Holt 1995; Oldenburg 1999), like joking, teasing, laughing, performing to friends during conversations, and engaging in other entertaining activities (Hattox 1996; Şeker 1997). Moreover, gambling and playing recreational and competitive games such as chess and backgammon were common in coffeehouses (Hattox 1996; Şeker 1997). For example, in the lower center of the miniature in figure 1, a competitive game between two backgammon players is depicted: one of the players has taken off his turban, and his bodily movements suggest that he is throwing the dice. Competition and gambling are additionally pleasurable due to the enjoyable experience of one's own performance (Arnould and Price 1993; Holt 1995) and the excitement of risk and imagining the possibility of winning (Cotte 1997).

The coffeehouse also provided physiopleasures (relaxation and refreshment; Tiger 2005) of the drink, the (coffee) break, the atmosphere, and sometimes more. The grander coffeehouses, with their carpeted floors and fine porcelain cups, provided highly comfortable, aesthetically pleasing, and sometimes al fresco enjoyment. Western traveler's notes depict coffeehouses that even had fountains inside or located outdoors in gardens or next to rivers, with a carpet on the ground, in various Ottoman cities (Ellis 2004; Hattox 1996). Even though smaller coffeehouses could not match such atmospherics, they still provided relaxation and refreshment to the masses. Moreover, sixteenth-century and seventeenthcentury coffeehouses were places of entertainment, where customers enjoyed listening to music or traditional romances and folk tales from storytellers or watching dancers or shadow puppet shows (And 1975; Bingül 2004; Hattox 1996). Figure 1 depicts a young man dancing and playing percussion at the center of the coffeehouse. At the left side of the miniature are four accompanying musicians; the youngest one (with a cap) is playing the tambourine.

Moreover, coffeehouses at times accommodated illicit 
pleasures of frivolous sexuality and drugs. Some of the puppet shows and songs were obscene and erotic (And 1975; Öztürk 2005). Perhaps a more significant sexual facet was the contact between the waiters and the clients. The interactions of attractive and well-dressed young male waiters with customers sometimes went beyond serving coffee (Ellis 2004; Hattox 1996). In figure 1, one of the men among the group of regulars is portrayed as caressing the face of a beautiful boy who bends toward him. The boy's ostentatious clothing and youth suggest that he is a dancer (And 2004). Travelers and commentators remarked that, in some coffeehouses, young charming boys displayed their skills "shamelessly" and the dancers and musicians pushed the limits of "sinfulness," sometimes tainting the reputation of the coffeehouse regulars (And 2004; Ellis 2004). In addition, much like the contained illegality of today's raves (Goulding et al. 2009), early modern Ottoman coffeehouses took in drug users seeking escape and ecstasy. A seventeenth-century chronicler, Katip Çelebi, states that drug users found coffee to be a life-giving substance that increased their pleasure (Gökyay 1980) and some drugaddicted consumers spent hours in the coffeehouse in a mode of drowsiness (Korkmaz 2004).

Finally, in coffeehouses, Ottoman men enjoyed ideopleasures (Tiger 2005) of mentally intensive literary or academic experiences. Figure 1 depicts a group of men in front of the furnace with papers and pens in their hands, reading and writing while sipping their coffees. Such men-of-letters enjoyed aesthetic pleasures of discussing poetry and religious sciences and assessing each other's works (Ünver 1963). Such leisurely discussions were transferred from home and work to the coffeehouse. In Ottoman society, before the coffeehouses were established, poetry meetings were either organized by wealthy patrons of higher social status or by poetry enthusiasts who were not close to these circles. The latter group regularly met at private homes or in shops or taverns (İpekten 1996). For example, poetry meetings took place at Zati's shop of fortunetelling in Istanbul, at spice shops of Nasuhi and Safahi in Edirne, and at Şeyhi's shop that sold trousers in Bursa (Ípekten 1996). In their work environment, poets enjoyed producing and discussing their poems. Organizing meetings at homes was costly to the host and meeting at taverns was not appropriate for Muslims since wine is forbidden in Koran (Şeker 1997). All such atmospherics and rituals for poetry gatherings transferred to the coffeehouses.

Men-of-letters were not necessarily of high status. For example, in figure 1, the inclusion of a Sufi dervish in the group is one indication that poetry discussions could be among people of different social positions. As mentioned in the methods section, the backgrounds of poetry enthusiasts differed significantly. For example, a janissary, Beliğ, was also a reputable poet and a coffee aficionado, and he wrote poems about coffee (Kıliç 1994). A sixteenth-century etiquette book, authored by a bureaucrat, identified studious coffeehouse patrons to be incompetent poetry enthusiasts, without the refined tastes of the elite (Şeker 1997). If the existence of amateur connoisseurs is an indicator of consumer culture (Belk 1995), the amateur poetry enthusiasts who frequented the coffeehouses are also indicative of the burgeoning Ottoman consumer culture. In part due to the coffeehouses, poetry was becoming a popular art form-as with today's popular music, it was consumed by people from various classes.

\section{Ottoman Coffeehouses: Revisiting the Formation of the Public Sphere}

Habermas (1992) defines "public sphere" to be a discursive sphere where people from different parts of the society get together and engage in debates about matters of mutual interest, thus forming public opinion and, if possible, reaching a common judgment about a debate. Thus, the public sphere is where politics and society meet. Habermas suggests that the eighteenth-century British coffeehouse exemplifies the development of bourgeois public sphere. We propose that the original source of the eighteenth-century British coffeehouse, the Ottoman coffeehouse, served to form the Ottoman public sphere.

The Ottoman coffeehouse was a place where people of diverse social positions met and engaged in debates. Menof-letters, scholars or amateurs, gathered to discuss poetry (Baykal 1981), and many others viewed and discussed theatrical performances, narrated stories, and shadow-puppet shows (Hattox 1996). Usually, tales and plays were satires of everyday life and the sociopolitical and economic conditions; if not, critical and reflexive accounts of current events were incorporated into the plots of often improvised performances (And 1975; Öztürk 2005). Hence, coffeehouse discussions played a not-so-trivial role in forming critical public opinion.

Moreover, coffeehouses were sites for critical action that linked political authority and the societal demands. For example, dervishes of the Qalandriyya order, a Muslim order influenced by Buddhist ascetics (Yazıc1 2009), attended coffeehouses to express their skepticism of political authorities (Barkey 1997). By the seventeenth century, janissaries not only gathered and criticized the state but actually planned riots while in the coffeehouses (Öztürk 2005). Accordingly, from the onset, the state considered coffeehouses as loci of resistance (Ünver 1963). Such subversion is perhaps one of the key reasons behind the prohibitions of coffeehouses (Hattox 1996).

Such critical performances and discussions point to the formation of a public sphere, if not a Habermasian one. Habermas (1992) regards the communicative interaction among reflexive and rational subjects as a prerequisite for the formation of the public sphere and critical public opinion against political authority. His premise entails an Enlightenment subject and a reflexive bourgeois class. Obviously, the early modern Ottoman coffeehouse consumer is not such a subject. However, it is arguable whether differentiation among the rational, aesthetic, emotional, and playful components of human communication is possible in the first 
place (Kömeçoğlu 2005; Tucker 1993). If subjects can shape the public sphere by any type of critical human communication (Tucker 1993), then satirical performances and humorous criticisms contribute to the formation of a public sphere in the coffeehouse (Kömeçoğlu 2005; Öztürk 2005). We advocate that critical communication, be it in the form of rational, aesthetic, emotional, or playful criticism, formed an early modern public sphere. In the absence of an established printing press and the linked presence of illiteracy, human communication, performances, and book readings in the coffeehouses helped create critical public opinion among the Ottomans.

Public discussion of a diverse array of issues, spreading across the numerous coffeehouses set the stage for individual consumer's thoughts and acts. Archival data sources demonstrate that coffee and coffeehouse consumption themselves became issues of debate. We find four discourses that pertain to the coffeehouse culture during the sixteenth and seventeenth centuries.

\section{MULTIPLE DISCOURSES}

The multiparty negotiations among four discourses-pleasure, Orthodox Islam, Sufi Islam, and health-shape consumers' coffeehouse practices, as well as the practices of the coffeehouse guilds, the state, and the religious institutions. Since individuals are moral beings who need to justify their acts (Campbell 1987), these discourses serve as justifications and frames, as well as motivations, for consumer practices.

\section{Pleasure Discourse}

As we have seen, Ottoman coffeehouses were sites of a variety of leisurely pleasures. A sixteenth-century poet depicts the coffeehouse as a site where the craving for pleasure was treated by providing various physiopleasures (Açıkgöz 1999, 8):

People addicted to hashish, şerbet (a sweet drink), and coffee The coffeehouse is the hospital of the hedonist

A poem from 1583 portrays the uniqueness of this social site (Ünver 1963, 53):

The meeting place of literati, the state of pleasure

Its style is appropriate, its art is unique

Search, but it will not be possible to find anything like that Coffeehouse has recently emerged

History, which is watching helplessly, said that

Like paradise, this is a unique place.

The poet seems to think that this novelty cannot be impeded, and he stresses its distinctive ideopleasures and heavenly physiopleasures.

Coffeehouses seem to have been often represented by such paradise metaphors in the public imagination. The paradise in Islam is the reward promised to the faithful. The Koran describes its pleasures: rivers flowing through gar- dens, pleasant weather, lovely shady places, male servants (glmans) serving wine, wines that do not intoxicate, vessels of silver and glasses of crystal, female servants with beautiful eyes (huris) and maidens with swelling breasts, comfortable sofas, green silk and brocade fabrics, gold and silver bracelets, delicious fruits, extravagant palaces, and "whatever the soul desires and in which the eyes delight" (Kinberg 2008). Ottoman hedonism was shaped in part by such myths in the Koran. The above poem is not the only period record of the paradise metaphor. Among others, Gelibolu'lu Mustafa Âlî, a bureaucrat, used the paradise metaphor in his description of a theatrical play that portrayed a coffeehouse. In Âlî̀'s accounts, young and fine-looking coffeehouse waiters represented the heavenly female and male slaves (Öztekin 1996), and the white and blue decorated porcelain cups in which coffee is served evoked the valuable glasses in which nonintoxicating wine will be served in the utopian paradise. Moreover, as some coffeehouses were located near rivers, in gardens, or had fountains, European travelers' accounts and engravings of them were also reminiscent of the Koranic paradise (Hattox 1996). Ottoman coffeehouses seem to have embodied the actualization of the sacred in a profane world (Belk, Wallendorf, and Sherry 1989) and their consumers to have experienced a metaphorical paradise, evocative of Campbell's (1987) imaginative hedonism.

If the coffeehouse was reminiscent of the utopian paradise in Ottoman imagination, perhaps these consumers were purchasing the sensual pleasures of paradise in this commercial site. This situation evokes the emergence of the therapeutic ethos, indicative of the consumer culture in Victorian England and late nineteenth-century America (Lears 1983): the transformation from Christian morality to a new ethos created a new subject who no longer aimed at salvation and the pleasures of heaven but instead sought pleasure in this world. In a similar manner, instead of opting for religiously appropriate practices, the Ottoman coffeehouse consumer sought pleasure in this worldly commercial site.

\section{Orthodox Islam on Coffee Consumption}

The pleasures of the coffeehouse were under scrutiny and intensely disputed since the state and the aligned orthodox Islamic authority usually considered coffeehouse consumption immoral or illegal. Excessive expenditures for the sake of pleasure and the carnal pleasures of extramarital sexual encounters were considered sinful (Berry 1994; Tiger 2005). The appropriateness of the coffeehouse, like the contemporary khat consumption in Ethiopia and Yemen (Anderson and Carrier 2006), was contested from a religious perspective.

By "orthodox Islam," we refer to the Sunnite interpretation of Islam among the sixteenth-century and seventeenth-century Ottomans. Orthodox Islam constituted the moral base of the religious and state authorities' interpretation of all sorts of issues, ranging from the functioning of the market to the consumption by the ideal Ottoman Muslim - the sultan's subject-and specifically coffee and coffeehouse consumption. Şeyhülislam, the chief religious 
authority, was employed by the state and worked in alliance with the sultan, the head of the state. While the sultan issued decrees, şeyhülislam issued fatwas (declarations).

In this view, the sultan's subject, an ideal Muslim, had to work hard to earn a living, meet his family's needs, and accumulate sufficient wealth without allowing greed to dominate his soul (Ülgener 1981). Wealth earned was to be consumed in appropriate ways, meeting Islamic obligations, such as pilgrimage, giving zakat (providing a portion of one's income to those less fortunate) or sadqah (donations), meeting personal and family needs, giving gifts, and supporting poets, as poetry reflected the refined aesthetics of the period (Öztürk 1991). Orthodox Islam prohibited philanthropy undertaken for self-promotion, excessive pleasure-seeking, and wasteful and conspicuous consumption (Öztürk 1991; Şeker 1997). Hence, the pleasures and the leisure of the coffeehouse were viewed to be sinful.

Decrees sent to the governors of Bursa, Istanbul, and Jerusalem during the late sixteenth century (Altınay 1988; Cohen 2004; Dağlıoğlu 1940), a fatwa (Düzdağ 1998), and an etiquette book (Şeker 1997) demonstrate that coffeehouse activities were perceived to be transgressive and contrary to orthodox Islam and its work ethic. Below we present parts from the sultan's decree sent to the governor of Bursa in 1578 to prohibit coffeehouses. The following is a simplified translation of the transcription of the original decree in Ottoman language:

In my territories, it is mandatory that Islamic law has to be applied, all of the forbidden things and things not allowed by Islamic canonical law are prohibited, banned, and abolished. Based on this, ever since, my higher orders have been issued repeatedly. While my highest glory, my decree has already been issued . . . especially coffeehouses, the gathering place for the sinful, should be banned, everybody should deal with his earnings and his job, and brigands should be eliminated and expelled. At the present, people gathered with young boys, took macun (hashish), beng (marihuana), and afyon (opium), drank wine and rakı [an alcoholic drink] with the pretext of coffee drinking, play backgammon, chess, and doplu [a game of the period], gamble, and spend their time with these illicit behavior and denials. Therefore, people who had been working in their jobs are now at disgrace, university students and assistants of judges became ignorant, rumors were spread all over the society by the above mentioned people. (Dağlığlu 1940, 87)

In this decree, the sultan avowed the ban on activities against the "Islamic canonical law," particularly coffeehouse consumption. Ineffective in implementation, such bans were repeated. Sensitive to the rumors regarding the negative effects of coffeehouse consumption and circumvention of his authority, the sultan had to reissue the decree in 1578 .

Similarly, and in response to an issue about coffeehouses and the kadıs (judge and governor of an administrative district) who condoned the operation of coffeehouses, the Şeyhülislam who served during the period 1545-74 delivered the following judgment. His fatwa declared, once again, the inappropriateness of coffeehouses (Andrews and Kalpaklı 2005, 283):

ISSUE: If it so happens that, although his lordship, the monarch, refuge of the faith (shadow of God on earth), has time after time [ordered] the prohibition of coffeehouses, they are [still] not prohibited and some people of the hooligan sort, in order to warm their gatherings, organize and set up entertainments and amusements such as chess and backgammon, gather those of the city who are addicted to love together with [beloveds] of pure, shining faces and evil deeds, eat electuaries of bersh [a combination drug], opium, and hashish, and on top of this, drink coffee, occupy themselves with the duplicitous arts, and also neglect the prescribed prayers, what is the canonical thing to do to the $k a d l$ who is in a position to prohibit and eradicate the aforementioned merchants and coffee drinkers?

RESPONSE: Those who engage in or abet the aforementioned unseemly [activities] should be prohibited and restrained by [means of] severe punishment and long imprisonment. Kadis who go easy in their chiding [of these] must be dismissed from their posts.

This fatwa constructs socio-, physio-, and ideopleasures as sinful and pronounces that both the consumers and the kadis who fail to contain them should be punished.

The repeated bans, the reissued decree, and the inability of the kadıs to control illicit coffeehouse activities all reveal that joint resistances of consumers and coffeehouse owners were effective. These consumers had at their disposal discourses other than solely orthodox Islam. In addition to the pleasure discourse, another discourse also played a crucial role in legitimizing pleasurable coffeehouse experiences: a different interpretation of Islam, Sufism. Orthodox Islam was the formal but not the most dominant discourse.

\section{Sufi Islam on Coffee Consumption}

Sufism is an ascetic-mystical trend in Islam characterized by distinct values, practices, and institutions (Knysh 2009). It has constituted a rival to orthodox Islam (Ülgener 1981). One characteristic is $d h i k r$, which refers to the directive of the Koran to remember God and cite his name (Chittick 2005). Sufis performed dhikr aloud, often with music, to accomplish remembrance. During evening dhikr rituals, coffee was consumed to stay awake. The first use of coffee for dhikr was claimed to be at Sheikh Şazeli's order in the thirteenth century in Africa (Hattox 1996). Therefore, Ottoman Sufis associated coffee drinking with this sheikh, a holy person who had received the grace of God.

During this period, orthodox Islam was critical toward the Sufis and their musical prayers (Öcalan 2000). Sufism, being a post-Muhammed interpretation of Islam, as well as other novelties associated with Sufism, such as smoking and coffee drinking, were considered to be bid'at, "illegal innovations, according to the Islamic law" (Gerber 1988, 70). However, Sufi orders had a significant role in Ottoman society; they were not marginal institutions. During the seventeenth cen- 
tury, Sufi orders proliferated and spread throughout the Ottoman lands, and the numbers of followers increased (Öcalan 2000). Besides, their activities were not restricted to the orders but rather permeated daily lives of many.

Attending Sufi orders was so common in the Ottoman society that the followers were not distinct from the general public. Sufi leaders would preach to the public, give lectures on Koranic sciences, teach reading and writing to the neighborhood children, have strong interactions with the guilds, and be influential in politics (Öcalan 2000). Besides, even the members of theological schools of orthodox Islam, the employees of the state bureaucracy, and the people in the palace attended Sufi orders. Sufis were interested in the arts, especially poetry, and during this period in the society, Sufi poetry reached its peak (Öcalan 2000).

The connection between coffee drinking and Sufism is expressed in the poetry of the period. Consider Nağzi's poem, which constructs coffee as sacred (Açıkgöz 1999). The poem tells a story of the rivalry between the personified coffee and wine. In the last part of the poem, coffee and wine go to court to give their statements to the judge. In his statement, coffee says that his birth was based on the Prophet Mohammed. When he (coffee) was in Ethiopia, King Solomon heard about him and brought him to Yemen. Then, coffee came to the lodge of the famous mystical leader, Sheikh Şazeli. He underwent ascetic treatment there, like the Sufis in their path to reach God. His covering was peeled off; he was roasted, pounded, and boiled. Then he left Yemen and went to Mecca, Damascus, Aleppo, and Cairo, and finally he arrived in Istanbul. This poem illustrates the ways Sufi images were attached to coffee. The poet used the ascetic treatment a Sufi had to experience to reach the grace of God in a Sufi lodge as a metaphor to explain the voyage of coffee seeds from the tree to the cup. Moreover, by incorporating it with religious figures like Prophet Mohammed and Sheikh Şazeli, he elevated the symbolic position of coffee and coffeehouses.

The diffusion of Sufism across the society and its informal power are likely to have made the Sufi discourse pervasive and potent in consumers' attempts to legitimize their coffeehouse consumption. While pleasure and Sufi discourses provided favorable and the orthodox Islamic view of the era unfavorable arguments, a fourth discourse provided controversial arguments regarding the practice: debates on health served the consumers, marketers, and the officials, either to legitimize or oppose coffee consumption.

\section{Health Discourse}

Coffee had been used as a medicine for various ailments since the tenth century (Schievelbusch 2000). Sixteenth-century and seventeenth-century Ottoman physicians debated its beneficial and harmful effects. The dryness, coldness, warmness, and moistness of coffee were linked to its harmful or beneficial effects (Açıkgöz 1999; Hattox 1996; Korkmaz 2004). For example, the dry nature of coffee was considered harmful to people who had anxiety-related sleeping problems but beneficial for depressive people and women (Korkmaz
2004). One physician named Zayni argued that coffee fostered melancholy; another, Antaki, warned that it decreased sexual activity and caused hemorrhoids and recurring headaches (Hattox 1996). Scholars and commentators also gave contradictory council: while Katip Çelebi cautioned drinkers about insomnia (Açıkgöz 1999), Kaysuni advised drinking coffee after meals to help digestion unless the person was in a phlegmatic mood (Ünver 1963).

The views of religious authorities and the public response to them reflected such health deliberations, too. Although the above-mentioned fatwa declared coffeehouse practices to be sinful, a later fatwa, issued by Bostanzade, a subsequent Şeyhülislam who served during 1589-92, affirmed coffee as a beneficial drink. It listed the numerous health benefits, such as releasing pain, preventing vomiting and inhalation problems, eliminating pustules in the eye, relaxing, sharpening thinking, banishing sadness, and preventing sleepiness. However, an anonymous poet criticized Bostanzade's fatwa:

\section{Nobody drinks the black faced coffee, except the disgraced \\ Does the hedonist drink that black faced sherbet? \\ Constipation and dryness is its continuing nature [Coffee] Incites illnesses within the body. \\ (Açıkgöz 1999, 48)}

This poet finds the coffee drinker sinful and the drink disagreeable and harmful to the body. In response, a famous poet, Suluki wrote in favor of coffee and blamed the other poet with lunacy and ignorance:

Oh lunatic! bad-tempered, disgraced, who blames coffee

Go and get physician's sherbet for your melancholy

Oh prodigal! Don't talk pretentiously about science that coffee is dry

Don't base the illness in your nature to it [coffee].

(Açıkgöz 1999, 49)

Another poet, Nev'i focused on the beneficial, stimulating, and productivity-enhancing effects rather than pleasurable aspects of coffee consumption:

Why the official behaves unjust to the coffee seller

If he drinks coffee, would a Muslim become an infidel?

Cannot lecture the next day, cannot read books at nights

If a teacher would not drink two cups of coffee

(Açıkgöz 1999, 13)

Such debates not only point to the approvals and disapprovals within the health discourse, but, more importantly, they indicate that coffee consumption was a noteworthy object of public opinion.

In the seventeenth century, the medical discourse on coffee traveled to Europe. For example, Sir Francis Bacon refers to the Turks when he mentions the mind-stimulating effects of coffee (Hattox 1996). A coffee advertisement, which was published in Public Adviser in 1657, reflects the British physicians' views on the health benefits of coffee 
and is very similar to Bostanzade's fatwa (Weinberg and Bealer 2002, 150):

Coffee, which is a very wholsom and Physical drink, . . . fortifies the heat within, helpeth Digestion, quickneth the Spirits, maketh the heart lightsome, is good against eye-sores, Coughs, or Colds, Rhumes, Consumptions, Head-ach, Dropsie, Gout.

The European health discourse was used to market coffee as a beneficial drink. Due to its alleged antierotic and mindstimulating effects, coffee became the favored drink of the Protestant ideology (Schievelbusch 2000). In England, unlike wine, coffee was thought to motivate people to work. Moreover, its antierotic nature represented asceticism and a life purified from sin. Twentieth-century U.S. coffee advertising also emphasized productivity and work as well as leisure. As with globalization today, during the early modern period, not only the goods but also the associated discourses traveled across borders, at times in reinterpreted and recontextualized forms.

In sum, we locate four countervailing discourses that contribute to the constitution of the coffeehouse culture. Although the formal orthodox discourse would be expected to have prevented coffeehouse consumption, we find that this is not the case. Consumption in coffeehouses was a heated topic of public debate. Many conflicting publics discussed the issue, voicing a multiplicity of opinions, as in other societies (Fraser 1999). Such diversity in opinions and debates also attest to the formation of a public sphere. Moreover, this setting provided a fertile ground for consumer resistance.

\section{RESISTANCE AND THE CONSTITUTION OF THE COFFEEHOUSE CULTURE AND THE CONSUMER}

The above-discussed sumptuary laws, bans on coffeehouses, decrees, and fatwas are institutional strategies (De Certeau 1988) that attempted to prescribe consumers' everyday lives. However, the repetitions of the sixteenth-century bans on coffeehouses, the reissuance of the decree reordering the governor to abolish coffeehouses, the apparent inability of the kadis to contain illicit coffeehouse activities, and the circumvention of sumptuary laws all reveal that the consumers did not obey the laws and regulations. Instead, they persevered in attending the coffeehouses and demanding its pleasures. This perseverance substantiates that these consumers of leisure contested the two-headed governance strategies - of the state and the religion-aimed at creating obedient subjects. Even their mere attendance to illicit coffeehouses was transgressive. Since transgression necessitates an agency that defies boundaries, breaks rules, and threatens the established order (Jenks 2003; Jervis 1999), it implies an active consuming subject. With their persistence, consumers played a role in shaping the market, the coffeehouse culture. Furthermore, consumers had at their disposal countervailing discourses that would have enabled them to negotiate the official discourse of orthodox Islam and give alternative meanings to and legitimize their resistive leisure consumption practices. Thus, the diversity of the discourses provided the potential for subjects to define themselves as consumers of leisure and the coffeehouse as a legitimate site of leisure. It also provided a similar potential to the guilds and the businessmen to resist the regulations and justify the coffeehouse. Over time, with the multiparty resistance and continuous redefinition of practices and values, the coffeehouse culture was instituted.

\section{Tactics of Resistance}

Consumers, as well as the guilds joining up with them, employed the three unofficial discourses while carrying out various forms of resistance or tactics (De Certeau 1988). Tactics are practices that transgressed the order and that were defined and justified through discursive negotiation processes. We find different modes of negotiating and legitimizing and mixed manners of leisure consumption entailing varied levels of transgression.

Transgressive Tactic: Leisure as Escape. Taking drugs was one of the most illicit pleasures of the coffeehouse. An account of a theatrical play about coffeehouses indicates how drug-using consumers utilized the discourses of pleasure, health, and Sufi Islam in resisting official Islam and establishing the coffeehouse as a site of leisure. This play was staged by a coffeehouse guild in 1582 during a festival in Istanbul, where the sultan was in the audience (Korkmaz 2004; Öztekin 1996). According to a period court narrator, Intizami, the scene opened with seemingly elite customers spending enjoyable time in a spacious corner of the coffeehouse, drinking coffee and conversing (Korkmaz 2004). After drinking their first cups of coffee, the ostensibly poor and drug-addicted customers asked the shop owner for more coffee and begged that he at least boil the grounds left in their cups for free. The elite, witnessing the situation, felt sympathy for the drug addicts and asked the coffeehouse owner to be generous. In the meantime, the addicts lapsed into drug comas, people gathered around them, and the coffeehouse owner was dismayed. The play concluded with the harmful effects of drugs and the beneficial effects of coffee: the drug addicts grasp the reality and feel worse after the temporary feelings of ecstasy and escape; coffee, on the other hand, helps one stay awake and eliminates the ill effects of drugs. Finally, the eminent Sheikh Sazeli, the alleged pioneer of the use of coffee in his order, was named as the reason for attending coffeehouses.

This play and the commentaries illustrate how coffeehouse consumption practices were legitimated through discursive negotiations. Most powerfully, Sufi discourse constitutes the finale. An understated but prevalent pleasure discourse- the sociopleasures and the physiopleasures-is evident in the references to the consuming styles of the elite, whom the court was more likely to favor than other attendees. The narrator, allied with the court and its official Islam, 
acknowledged, even if mockingly, the health discourse at work in the play as well.

Paradoxically, the very portrayal of drug addicts and their coffeehouse experiences constructs the coffeehouse as a site of transgressive escape from everyday life and as a site of ecstasy akin to the contemporary demand for prohibited things such as illicit raves (Goulding et al. 2009), or more broadly, transgressive consumption desires (Belk et al. 2003). Like cigarettes (Klein 1993), what makes illicit coffeehouse activities pleasurable is resisting reason that tells us not to do something bad or harmful. While some period books, especially those presented to or sponsored by the court attribute drug usage in coffeehouses to "a few despondent idlers" (Korkmaz 2004; Şeker 1997), other data indicate that it was more widespread. For example, opium consumption was reportedly very popular among the elite from the seventeenth century onward (Koçu 1946). Not only the poor and idle drug addicts but also the wealthy and the respectable seem to have enjoyed transgressive escape in coffeehouses.

Thus, a wide range of consumers, rather than accept the prohibitions and be the obedient subjects of the sultan, chose to engage in improper or illicit activities. Despite, or perhaps due to, the risks of being arrested or health, they pursued leisurely pleasures and escape in the coffeehouse-a venue for such transgressions. It is clear that the newly forming coffeehouse consumer was capable of resisting the authorized order and constructing himself as a consumer of leisure.

A Less Transgressive Tactic: Leisure for the Sake of Poetry. Meeting in the coffeehouses for the sake of enjoying the ideopleasures of poetry was a manner of coffeehouse consumption usually attributed to the admired menof-letters. Another account of the above-mentioned festival also includes a theatrical play, staged again by a coffeehouse guild. It reveals how poetry enthusiasts negotiated the discourses of pleasure and orthodox Islam in defining their coffeehouse consumption practices (Öztekin 1996). Gelibolu'lu reports that this play started with a scene from a peaceful coffeehouse, where the owner was making coffee and young customers were reciting poetry from printed sheets (Öztekin 1996). Suddenly, officers who were responsible for market regulations attack the coffeehouse for not observing the ban. The owner of the coffee shop escapes, but officers destroy the coffeehouse, break the coffee cups, and tie the hands of poetry-reading customers. The play ends with coffeehouse guild members' complaints to the sultan that unjust offenses were frequently applied despite the peaceful conduct at the coffeehouses and their pleas for putting an end to the ban and the raids. Gelibolu'lu Âlî comments that, although the sultan enjoyed the play and removed the ban, coffeehouses were banned again later (Öztekin 1996).

In this account, the guild members' comments reveal that such raids were framed as an unjust punishment of poetry lovers. The ethos of "justice" was used in support of the consumers of illicit coffeehouses and in requesting the pre- vention of such injustice by the representatives of the sultan. Besides, although orthodox Islam regarded coffeehouse consumption to be harmful to society, it considered poetry reading and writing to be appropriate types of pleasure-seeking and forms of refined aesthetic taste (Öztürk 1991). Moreover, morality books of the period recommended supporting poets and giving gifts to them (Öztürk 1991), much like charitable donations and sponsorships. Thus, the admirable status of poetry and its ideopleasures gave rise to the overlap between orthodox Islam and the pleasure discourse, which put the former to its own use in this case. Although enjoying leisure for the sake of poetry was less transgressive than the use of drugs, the coffeehouse consumer still transgressed by attending the illegal site in the first place. Joining hands with the coffee shop guilds in using the countervailing discourses, he rejected the legal authority and instead constructed himself as a consumer of leisure.

The Least Transgressive Tactic: Limiting Leisure. Orthodox Islam's work ethic deemed spending long hours in the coffeehouse to be improper and detrimental to society as it took time away from earning a living and/or praying. However, a mix of the discourses of pleasure, Sufism, and orthodox Islam enabled justification of spending a limited amount of time there. First, the spiritual role of coffee drinking in Sufi rituals was cited. For example, the sixteenthcentury Sufi poet Süluki criticized the people who were against coffeehouses as being ignorant of the origins of drinking coffee in Şazeli's Sufi order (Açıkgöz 1999). A period scholar, Gelibolu'lu, describes the act of limiting leisure in his etiquette book as follows:

Some members of Sufi orders come [to coffeehouses]. They find it appropriate just to drink their coffee and leave. The consideration of such people is that coffee is the elixir of the ones who follow God because coffee ingratiates itself with someone like Sheikh Şazeli, who reached the grace of God. While he [coffee] was a black tanned beloved from Yemen, the fortune in the glance of the Sheikh made him the beloved of the hearts. Therefore, the people continuing mystical orders are in love with him. (Şeker 1997, 364)

This tactic was the least transgressive also because spending a short time at a site of leisure demonstrated some obedience to the work ethic. Then the enjoyment obtained from the coffeehouse experience was allegedly limited only to the physiopleasures of tasting coffee and not the leisurely activities. Overall, we see that consumers resisted the order by attending the coffeehouse and that they formed and justified such trangressive practices by mixing various ethics.

\section{Normalization of the Consuming Subject and Legalization of the Coffeehouse}

Such resistance was neither limited to a small group of rebels nor reserved for individuals. It was also not inconsequential. Enacted repeatedly, by a much broader range of people than the state and the religion would have liked, the 
above tactics served to construct different self-ethics by a range of coffeehouse goers, who, along with coffeehouse owners, persisted in resisting until the coffeehouse was legalized and normalized. Concurrent with the transformation in the state and the religious institution, the consumer subject who resisted the order and was active in defining self-ethics was normalized through interactions within the newly emerging public sphere.

Extensive Resistance across Roles and Classes and Constructing Self-Ethics. Official accounts, such as decrees and the period festival and etiquette books, attributed particular tactics to specific types of people. Transgressive escape was attributed to drug users, assumed to be idlers, or to janissaries, who supposedly wasted entire days in the coffeehouse "gossiping, backbiting, and self-praising" (Şeker 1997, 218); consumers who limited their time in the coffeehouse were believed to be Sufis; and consuming leisure for the sake of poetry was accredited to the men-of-letters, the elite (Dağlıoğlu 1940; Korkmaz 2004; Şeker 1997). However, portrayals of the everyday lives of poets, such as Gulami, Atâ, and Beliğg, in Aşık Çelebi's period anthology and in other sources on everyday life, reveal that the practices and tactics of consumers were not bound by their social positions: for example, many reputable poets used drugs, and some janissaries were also poetry enthusiasts (Kılıç 1994; Koçu 1946).

One example that indicates that not only the "despondent idlers" but also ruling class members could enjoy the pleasures of drugs, albeit alongside the ideopleasures of poetry, was Gulami. A sixteenth-century poet of slave origin, he was known for his addiction to narcotics and was seen in coffeehouses in a state of drowsiness (K1lıç 1994). After completing his education at a theological school, he was appointed as an assistant functionary, thus became a member of the ruling class. He reportedly attended the coffeehouse for both transgressive escape and for the sake of poetry. Gulami's life story also indicates that someone from the lowest echelons of society could get a prestigious education and attain an esteemed status; it thus illustrates the abovediscussed fluidity of social structure.

Another poet, Atâ, was a physician. Aşık Çelebi states in his tezkire that, although Atâ was a court physician, he spent most of his time in the coffeehouse and went home only occasionally, "as if a guest" (Kılıç 1994). He uses a telling magic lantern metaphor in describing Atâ: a regular, like the indispensable decoration of the coffeehouse, whose pale and slender look due to drug addiction resembled the dim light of the lantern. Atâ's story demonstrates that even a person so close to the palace and with an education based on orthodox Islam could transgress the work ethic and become a coffeehouse regular.

Yet another role-crosser was Beliğ: a janissary, a famous poet, and a coffee aficionado. Aşık Çelebi portrays Beliğ as more of a poet than a responsible man-at-arms. Beliğ's following poem demonstrates the popularity and the commercial value of coffee and the physiopleasures of coffee and the coffeehouse (Kılıç 1994, 191).
Although coffee is not as graceful as wine

The blood of that black-faced [coffee] is still warm

Does it [coffee] have a match or an equivalent in attracting customers?

Who wishes to get attention [literally a warm face], wants it ...

. . That world seducer took the place of wine.

Has a desire for money, wanders around, coinizes [becoming coin]

I don't know if the coffeehouse owner's boy [servant] is deceitful/prostitute

Finding the taste of wine superior to coffee, Beliğ expresses his admiration for the forbidden wine. He remarks that coffee substituted for wine by providing warmth. The last verse of the poem moves to a young servant in the coffeehouse. Beliğ might be concerned if the servant exploits consumers by overcharging them or if he cheats on his lover-either Beliğ himself or someone else. At the least, this last verse implies his interest in young servants and the carnal pleasures of the coffeehouse. Aşık Çelebi's account attests that Beliğ enjoyed the refined taste of poetry even though he was merely a janissary and wine even though he was a Muslim; perhaps he even had sexual encounters with boys. Beliğ seems to have merged transgressive tactics with the dignified joys of poetry - an art not expected from a janissary.

Thus, people from different social classes consumed coffeehouses, at times in unprescribed or unexpected ways. The ruling class consumed drugs, and janissaries wrote poetry. Consumers could combine tactical resistances in their own ways to define and legitimate their particular manner of coffeehouse consumption. It is clear that many did not accept the moral codes but instead constructed their own ethics. Foucault $(1990,28)$ portrays this type of subject as someone who "delimits that part of himself that will form the object of his moral practice, defines his position relative to the precept he will follow, and decides on a certain mode of being that will serve as his moral goal." The range of moral modes and goals underlying different consumer tactics implies that Ottoman coffeehouse consumers were constructing their particular self-ethics while resisting orthodox Islam. For example, if spending hours idle in the coffeehouse or losing consciousness to drugs were too inappropriate for one, enjoying leisure time within the limits of the work ethic was acceptable. Or consider Beliğ's self-ethics: it was appropriate for him to enjoy the sociopleasures and ideopleasures of poetry discussions and the physiopleasures of drinking coffee or the religiously forbidden wine or even the contact with attractive young servants. Therefore, the Ottoman coffeehouse consumer was not only active in terms of resisting prescriptions but also in defining particular selfethics: he had become a consuming subject.

Interacting with others, across social classes, such subjects witnessed diverse manners of resistance in the coffeehouse. They also heard or participated in discussions and readings of poetry, puppet theaters, and stories that were frequently 
critical of the authorities. The site was ripe for mimesis (Girard 1987) not only within but also across social classes. Thus, a broad range of individuals of different social positions had the potential to use resistance tactics, define selfethics, and hence enact becoming consuming subjects. This potential was not restricted to a small group: the consuming subject of mass consumption was in the forming. The resistance tactics spread widely via the public debates about coffeehouses. The discursive public sphere constituted an environment where different forms of consumption were negotiated regularly, repeatedly, and, over time, normalized. Despite the dire consequences of recurrent prohibitions, coffeehouses became widely popular. An analysis of judicial records of the seventeenth-century Kudus, where the number of lawsuits about coffeehouses decreased and disappeared gradually, also indicates normalization of coffeehouse consumption (Cohen 2004). Thus, Gulami, Atâ, Beliğ and many other consumers who frequented the once illicit coffeehouses ultimately prevailed over the state and the religion.

Institutional Resistance and the Transformation in the State and the Religious Institution. Consumers were not alone in constituting themselves as consuming subjects and the coffeehouse culture. Institutions also played important roles. Coffeehouse owners and their guilds resisted the political and religious authority by retaining their businesses despite the bans and punishments. They utilized similar types of tactical resistances as the consumers in legitimating coffeehouse consumption and negotiating with the authority, as exemplified in the theatrical plays they staged and presented to the sultan. In addition, with such theatrical plays, the guilds expanded the public debate about coffeehouse consumption outside the physical space of the coffeehouse. The ongoing nature of their negotiations is perhaps indicated by the temporary lifting of the ban after the sultan watched one of the plays. The state's inconsistent conduct in the face of insistent consumer and marketer resistance signals its concession to negotiating with the consumer and the marketer. The temporary nature of the bans resonates with what Pamuk (2004) calls the pragmatic, flexible, and negotiable central bureaucracy co-opting and incorporating into the state the social groups that rebelled against it. It also accords with other evidence regarding the loosening of the state's grip on the markets in general at the period (Pamuk 1998). Over repeated bans and their abolishment, the resistance of the coffeehouse owners became a routine aspect of their conduct as well. A new habitus was in the forming (Bourdieu 1989).

As coffeehouses developed to occupy a significant place in social life, their input to the economy increased. For example, the late sixteenth-century tax registers from Kastamonu (an Anatolian town, away from the more central Istanbul and Bursa) included a new item: taxes levied upon the sale of coffee. In the next century, there was a large increase in the demand for coffee, and enormous amounts of coffee were traded (Faroqhi 1986). Gerber (1988) reports that a merchant who traded between Egypt and Bursa left more than one and a half tons of coffee among his possessions when he died in 1677. By the seventeenth century, even some bureaucrats and theology professors had acquired lucrative coffeehouses (Baykal 1981). The consumers' and the guild's joint resistances shifted the role of the market from that of maintaining social order to generating revenue for the state.

While coffeehouse consumption was turning into an ordinary practice, with increasing economic benefits to the state, the religious authority's views regarding coffee and coffeehouse consumption shifted as well. We discussed above the contradictory fatwas issued in the span of two decades, first against and then in favor of coffeehouses. The latter fatwa declared coffee as appropriate, stating that it does not make people drunk and listing its health benefits. The period chronicler stated that this fatwa legitimated coffee consumption in the Ottoman society (Baykal 1981). Interestingly, in this case, the religious authority used a secular and a rational rather than a religious discourse in endorsing coffee and coffeehouses.

As (consumer and market) resistance became commonplace and coffeehouse consumption an everyday activity, yielding greater tax income to the state, the once-repeated bans were totally lifted in the late seventeenth century. Initial resistance and the subsequent normalization of coffeehouses was concurrent with, first, the inconsistencies, and later, the changes in the discursive practices of the state and the religious authority. Repeated consumer and marketer transgressions paved the way to the reproduction of coffeehouse culture by continuously redefining practices and values. The coffeehouse, including its objects, rituals, layout, and design and the roles of its customers, owners, servants, and performers was formed among the countervailing discourses in the Ottoman public sphere. As this novel commercial site of leisure was being formed and legalized, an active consumer who had the ability to use preferred resistance tactics and define his own particular consumption practices and self-ethics was in the forming too.

\section{DISCUSSION}

Our cultural-historical analysis contributes to a less studied area of consumer culture theory: historical and institutional shaping of the consumer and the marketplace as a social category (Arnould and Thompson 2005). We find that both an active consumer and a market were forming within the budding sixteenth- and seventeenth-century Ottoman consumer culture, through the interactions of market actors, such as consumers, marketers, the state, and the religious institutions. In doing so, we also contribute to the view that, rather than posing two authentic forms, the global and the local have each been sociohistorically constructed (Kjeldgaard and Ostberg 2007): we empirically demonstrate such foundations at sixteenth-century Ottomans, earlier than the seventeenth-century Europe that Kjeldgaard and Ostberg propose.

The present study is restricted to leisure consumption among male consumers in Ottoman coffeehouses. While our findings are limited to men, we provide a counterpoint to 
historical studies, most of which locate women as the vanguard of consumption and formation of consumer culture (Campbell 1987; Rappaport 2004; Reekie 1993; Veblen 1899/1994; Vickery 1993; Walkowitz 1992). We show that men also played a significant role in this formation-at least for leisure consumption. In addition, we find the use of a combination of visual and textual data highly informative and thus recommend it for historical research.

Our study supports and extends two broader theoretical claims: (1) consumption resolves the tension between the individual's pursuit of pleasure and morality (Belk et al. 2003) and (2) market cultures are cocreated through discursive negotiations and practices (Peñaloza 2000; Thompson 2004). Much like Belk et al.'s (2003) self-managing consumer who moderates his or her consumption acts in order to feel or become an ethical person, the Ottoman coffeehouse consumer was active in defining his self-ethics. We extend Belk et al. (2003) by introducing and specifying the role that transgression plays in the formation of selfethics: consumers transgressed in different ways and at different levels depending on their negotiation of the tension between the pursuit of pleasure and the pursuit of religious morality. We also incorporate the institutional forces and the interaction between the individual and the institutional actors in this process. In a countersymmetrical fashion, our study extends Peñaloza's (2000) conceptualization of the cocreation of market cultures by drawing attention to the tensions at the individual level. Our explication of the roles played by the state and the religious institution extends Peñaloza (2000) and Thompson (2004) by situating the cocreation of market cultures in a network of actors broader than the marketer-consumer dyad; actors include customers, marketers-that is, coffeehouse owners- the state, and the religious institution. We emphasize that the formation of market cultures and their consuming subjects is not only a sociocultural but also a political and moral phenomenon located in the broader public sphere.

The formation and normalization of Ottoman coffeehouse culture and its consumer subject rest on the fundamental tension between the Ottoman man's pursuit of socio-, ideo-, and physiopleasures and his pursuit of morality: he is caught between the transgressive joys of the coffeehouse and his morals. He attempts to resolve this tension by drawing from various resources and taking advantage of the opportunities available in the nexus of a growing public sphere, multiplicity of discourses, mutual resistances of the consumer and the market, and flexible political and religious institutions. If we continue with the focus on the individual consumer, he redefines and justifies his pleasurable yet transgressive consumption practices and tactics by using the countervailing discourses circulating in the public sphere. Emergence of a public sphere, in turn, was enabled by the fluid social structure of the era as well as the features of the site. The socially mobile urbanites had the opportunity to interact with people of all walks of life in the socially leveling environment of the coffeehouse - a novel site with few clearly defined norms. We have seen that coffeehouses constituted an ideal context for a public sphere to flourish where interaction among consumers with different social positions generated playful, aesthetic, and rational modes of communication and criticism. Such interaction is likely to have created a mimetic process where various tactics were adopted, appropriated, negotiated, and redefined by a very diverse group of consumers. This finding has an interesting implication for the literature on public sphere: consistent with much of the consumer culture theory literature, criticism can be politically effective even if based on playful communicative interaction rather than a purely rational one.

The vibrancy of this context and the eventual legitimization of coffeehouse consumption were clearly shaped by the coexistence of two strong religious discourses rather than only one. This situation is similar to the coexistent Calvinist and humanistic ethics in sixteenth-century and seventeenth-century Netherlands (Schama 1987) and the Protestant and Romantic ethics in eighteenth-century England (Campbell 1987), eras when European consumer culture was developing. The Dutch humanist discourse provided legitimization for expenditure, rather than capital accumulation, as a way to free oneself from the suspicion of greed. It promoted expenditure for the benefit of community, such as philanthropy, lending to public institutions, or even spending money for feasts and providing a comfortable life to one's own family (Schama 1987). Similarly, the Romantic ethic made room for hedonism in England (Campbell 1987). It seems that, in different cultures, the duality of ethical discourses allowed for legitimization of consumption and development of consumer cultures. Dutch humanism, British romanticism, and Ottoman Sufism supported philanthropic and domestic, hedonic, and leisure consumption, respectively. Thus, in a context of dual ethics, public debate, multiparty resistance, and repeated transgressions, the coffeehouse consumer and his consumption were formed.

Consumers were supported by an ally-marketers. Coffeehouse owners' resistances, such as their disobedience of the codes and theatrical plays, contributed to the persistence of the coffeehouses and therefore provided the opportunity for consumers to repeat and experiment with their transgressive and pleasurable actions. Embedded in such a public sphere of diverse modes of behavior and discourses and supported by the marketers, the coffeehouse consumer was able to defy prescriptions and instead assemble his own ethics. Repeated and proliferated, the once transgressive coffeehouse consumption practices became routine in the everyday life of Ottoman men. Such routinization reveals an active consumer subject: he had been effective in forming his self-ethics and enacting his personal understanding of how to spend one's leisure appropriately. This reveals a transformation from an obedient (sultan's) subject to a consuming subject who resists the order and utilizes alternative discourses to define his own pleasurable practices and selfethics.

Finally, the increasing flexibility of the state, as well as the inconsistencies in the discursive practices of the state and the religious authority, were also opportune for the normalization of the coffeehouse. Rather than applying rigid 
rules, the state was open to negotiations with the guilds and the eventual change of conventions. The emergent public sphere, including the proliferating defiances and negotiations of marketers and consumers, constituted the loci of resistance to the political sphere, consistent with other evidence regarding the presence of a public sphere and political negotiation in the Ottoman society of the era (Kafadar 1994). As coffeehouse consumption was being routinized over a century, the state's and the religious authority's discursive practices were transforming as well. Eventually, and similar to what occurred in eighteenth-century England (Agnew 1993), markets gained agency in determining the attributes of truth and materiality: what was regarded to be appropriate about coffee, coffeehouse, leisure, and pleasure was defined by market relations instead of religion.

In sum, the constitution of an active consumer and a coffeehouse culture was enabled by a particular set of conditions: emergent public sphere, multiplicity of discourses, consumer-marketer alliance in resistance, and the increasing flexibility of political and religious governance. In the process, each party and field was transformed.

\section{Implications for the Literature on Ottoman History}

With a few recent exceptions (Faroqhi 2002; Grehan 2007; Quataert 2000), consumption is an underresearched topic in Ottoman historiography. Most research focuses on production, material culture, or trade rather than consumption; the few studies that approximate consumption emphasize the luxury possessions in the palace or among the elite (Artan 2000; Faroqhi 2004; Neumann 2004; Tezcan 2004). Thus, our research is an early and preliminary exploration of the more ordinary Ottoman consumer and the broader consumer culture. Therefore, this study extends Ottoman consumption studies from a unidirectional study of objects to a study of complex market relationships between products, consumers, and institutions that define Ottoman consumer culture. Our findings call for complementary investigations, perhaps focusing on bathhouse consumption among women.

\section{Reflections on Consumer Resistance}

Contemporary consumer research constructs a resisting and self-defining subject who juxtaposes different meanings from a variety of discourses in order to assemble own identity instead of accepting the impositions from the marketer (Belk et al. 2003; Brown et al. 2003; Firat and Venkatesh 1995; Kozinets et al. 2004; Maclaran and Brown 2005; Thompson 2004). This resisting consumer is understood to gain a certain level of freedom of choice against the marketer in the capitalist market system (Denegri-Knott, Zwick, and Schroeder 2006; Slater 1997). Yet, another strand of research argues that the contemporary consumer is not powerful or revolutionary enough to change the market structure (Holt 2002). We find that the Ottoman consumer resisted and gained a certain level of freedom of choice, not against the marketer but against the impositions of the state and the religious institution, both of which were market actors too. He succeeded in this situation where he and the marketer had joined forces in enacting resistance. Thus, the market and the consumer do not always have to be oppositional; the market can help the consumer resist and transform the order. Furthermore, our findings, in accordance with Holt (2002), imply that, in order for consumer resistance to be successful, an individual's alliance with an institution-even the market itself-and the existence of a public sphere are necessary.

Interestingly, Giesler's (2008) results about music consumption cohere with our proposition. Akin to the Ottoman coffeehouse consumer, Giesler's $(2008,746)$ contemporary consumer (re)defines self-ethics- - "downloading was not a cultural transgression, as producers promoted, but rather a liberatory move away from aesthetic and cultural repression" - and has a role in transforming the music market. And like the Ottoman case, this happens when the individual joins forces with an institution-the Internet, which at the same time is a medium of the public sphere. Thus, it seems that when a subject and an institution establish an alliance in resisting the existing market structure, they can successfully transform the market structure.

While research has tended to focus mostly on the consumer-marketer relationship, other marketplace actors also play important roles in consumption. In addition to the Internet (Giesler 2008), market actors include science/medicine (Thompson 2004) and religion (Sandikci and Ger 2010). Also, consider the governmental attempts to create ideal consumer-citizens who commit to consumption in order to fuel the economy (Cohen 2003) or the prohibitions on smoking, gambling, or rave (Goulding et al. 2009). Thus, we suggest that the interaction and potential alliance between the consumers and each of a network of market actors are worthy of further research on consumer resistance and market transformations.

\section{Reflections on Understandings of Consumer Culture and the "Consumer"}

In following Poster's (1989) call for investigating the role of consumer subject in the development of consumer culture, we demonstrate that "democratization" of consumer culture goes well beyond a spread of consumption to masses (McKendrick 1982; Plumb 1982). There was also democratization in the sense of active participation in institutional, individual, and cultural domains (Benhabib 1999; Habermas 1992). The changes in the legislation on coffeehouses as a result of joint resistances of the guilds and the consumers, the constitution of a variety of self-ethics, and the reproduction of coffeehouse culture entailed participative formations.

In accordance with Borgerson (2005), we problematize the premise of the recent advent of a new type of postmodern or posttraditional consumer. Consumer research locates this active consumer as a subject that is identified with the capitalist or the late capitalist market system (Firat and Dholakia 
1998; Firat and Venkatesh 1995; Slater 1997). Obviously, the early modern Ottoman context was very different than any modern capitalist system. However, the fluidity and the variety of roles, authorities, and discourses, as well as the resistance tactics, imply that the active consumer may not be as recent or even a chronological phenomenon as many consumer researchers think. Similarly, we see that markets and consumers have long been embedded in global networks and that the hybrid global-local forms of consumption objects go back to at least the sixteenth century. We also see that not only the goods but also the associated discourses traveled across borders, albeit in reinterpreted and recontextualized forms, as with contemporary globalization.

As Trentmann $(2006,51)$ suggests, "the genealogy of the consumer is not a linear story, nor does it converge." Existence of an active consumer in the early modern Ottoman era challenges the claim that modern consumer culture originated during seventeenth-century to nineteenth-century Western Europe and North America and then spread throughout the globe (Campbell 1987; McCracken 1988; McKendrick et al. 1982; Mukerji 1983; Roche 2000; Schama 1987). Contrary to (possibly Orientalist) expectations, Ottoman coffeehouse culture may well have played a major role in the diffusion of leisure consumption. Investigations of formations of consumers and consumer cultures in a variety of places and eras and with alternative historical trajectories will enlighten consumer researchers' understandings of nonlinearity and of ethnoconsumerisms (Venkatesh 1995).

Moreover, studying alternative historical and contemporary contexts will help researchers identify generalizations based on the commonalities in the formation of different consumer cultures and subjects. Our findings corroborate Trentmann (2006, 21), who shows that the development of the consumer points to "the centrality of political tradition, civil society and ethics through which agents discovered themselves as active consumers," even though our consumers lived earlier and in a different geography. It is evident that future studies on the political and ethical setting of consumption, as well as a closer dialogue between consumption studies and contemporary historiography, are called for.

Another crucial commonality with investigations of more recent eras is that the sixteenth-century and seventeenth-century Ottoman consumer is also a consuming subject in that he pursued his own choices and defined his own ethics. This consumer is similar to Campbell's (1987) eighteenth-century English consumer in being active and self-defining. However, while Campbell emphasizes the role of imaginative hedonism, our findings converge on a transgressively hedonistic consumer: he followed his own hedonistic choice by fighting for it. Granted, his choice was also fed by imaginations such as the paradise metaphors. Our findings imply that transgression may well have been constitutive of "the consumer," as it is constitutive of contemporary consumer desires (Belk et al. 2003); that is, transgression is integral and vital for consumer subjectivity. Alternatively, consumption serves a venue for transgression, complementary to its role in identity construction and relationship building. And markets, just as they can be a target for resistance, may also provide an ally and resource to the consumers in their quest for transgression of some social order of everyday life.

\section{REFERENCES}

Abou-El-Haj, Rifa'at 'Ali (2005), Formation of the Modern State: The Ottoman Empire, Sixteenth to Eighteenth Centuries, Syracuse, NY: Syracuse University Press.

Abu-Lughod, Lila (1999), Veiled Sentiments, Berkeley: University of California Press.

Açıkgöz, Namık (1999), Kahvename, Ankara: Akçağ.

Agnew, Jean-Christophe (1993), Worlds Apart: The Market and the Theater in Anglo-American Thought, 1550-1750, New York: Cambridge University Press.

Altınay, Ahmet Refik (1988), 16. Asırda İstanbul Hayatı, İstanbul: Enderun.

And, Metin (1975), Karagöz: Turkish Shadow Theatre, Ankara: Dost.

- (1993), 16. Yüzyılda İstanbul, İstanbul: Akbank. (2004), Osmanlı Tasvir Sanatları 1: Minyatür, İstanbul: Türkiye İş Bankası.

Anderson, David M. and Neil Carrier (2006), "'Flowers of Paradise' or 'Polluting the Nation'? Contested Narratives of Khat Consumption," in Consuming Cultures, Global Perspectives, ed. John Brewer and Frank Trentmann, New York: Berg, 145-66.

Andrews, Walter G. (1985), Poetry's Voice, Society's Song, Seattle: University of Washington Press.

Andrews, Walter G. and Mehmet Kalpakl1 (2005), The Age of Beloveds: Love and the Beloved in Early Modern Ottoman and European Culture and Society, London: Duke University Press.

Arendonk, Cornelis van (2009), "Kahwa," in Encyclopedia of Islam, ed. Peri Bearman, Thierry Bianquis, Clifford Edmund Bosworth, Emeri van Donzel,and Wolfhart P. Heinrichs, Brill Online, http://www.brillonline.nl/subscriber/entry?entry = islam_COM-0418.

Arnould, Eric J. and Linda L. Price (1993), "River Magic: Extraordinary Experience and the Extended Service Encounter," Journal of Consumer Research, 20 (June), 24-55.

Arnould, Eric J. and Craig J. Thompson (2005), "Consumer Culture Theory (CCT): Twenty Years of Research," Journal of Consumer Research, 31 (March), 868-82.

Artan, Tülay (2000), “Aspects of the Ottoman Elite's Food Consumption: Looking for Staples, Luxuries, and Delicacies in a Changing Century," in Consumption Studies and the History of the Ottoman Empire, ed. Donald Quataert, New York: SUNY Press, 107-200.

Arvidsson, Adam (2003), Marketing Modernity: Italian Advertising from Fascism to Postmodernity, London: Routledge.

Ayvazoğlu, Beşir (1992), Güller Kitabı: Türk Çiçek Kültürü Üzerine Bir Deneme, İstanbul: Ötüken.

Barkey, Karen (1997), Bandits and Bureaucrats: The Ottoman Route to State Centralization, Ithaca, NY: Cornell University Press.

Batchelor, Robert (2006), "On the Movement of Porcelains: Rethinking the Birth of Consumer Society as Interactions of Exchange Networks, 1600-1750," in Consuming Cultures, Global Perspectives: Historical Trajectories, Transnational Exchanges, ed. John Brewer and Frank Trentmann, New York: Berg, 95-122. 
Baxandall, Michael (1988), Painting and Experience in 15th Century Italy, Oxford: Oxford University Press.

Baykal, Bekir Sıtkı, ed. (1981), Peçevi Tarihi, Cilt 1, Ankara: Kültür Bakanlığı.

Belk, Russell W. (1995), Collecting in a Consumer Society, London: Routledge.

Belk, Russell W., Güliz Ger, and Søren Askegaard (2003), "The Fire of Desire: A Multi-sited Inquiry into Consumer Passion," Journal of Consumer Research, 30 (December), 326-51.

Belk, Russell W., Melanie Wallendorf, and John F. Sherry Jr. (1989), "The Sacred and the Profane in Consumer Behavior: Theodicy on the Odyssey," Journal of Consumer Research, 16 (June), 1-38.

Benhabib, Seyda (1999), "Models of Public Space: Hannah Arendt, the Liberal Tradition, and Jürgen Habermas," in Habermas and the Public Sphere, ed. Craig Calhoun, Cambridge, MA: MIT Press, 73-98.

Berry, Christopher J. (1994), The Idea of Luxury: A Conceptual and Historical Investigation, Cambridge: Cambridge University Press.

Bingül, İlyaz (2004), "Kahvehane ve Eğlence," Toplumsal Tarih, 126 (Haziran), 70-75.

Bonnell, Victoria and Lynn Hunt (1999), "Introduction," in Beyond the Cultural Turn, ed. Victoria Bonnell and Lynn Hunt, Berkeley: University of California Press, 1-34.

Borgerson, Janet (2005), "Materiality, Agency, and the Constitution of Consuming Subjects: Insights for Consumer Research," in Advances in Consumer Research, Vol. 32, ed. Geeta Menon and Akshay R. Rao, Duluth, MN: Association for Consumer Research, 439-43.

Bourdieu, Pierre (1989), Distinction: A Social Critique of the Judgment of Taste, London: Routledge.

Braudel, Fernand (1980), On History, Chicago: University of Chicago Press.

- (1992), Civilization and Capitalism, 15th-18th Century: The Structure of Everyday Life, Vol. 1, Berkeley: University of California Press.

_ (1993), II. Felipe Döneminde Akdeniz ve Akdeniz, Dünyası, Cilt 1, İstanbul: İmge.

Brewer, John and Roy Porter, eds. (1993), Consumption and the World of Goods, New York: Routledge.

Brown, Stephen, Robert Kozinets, and John F. Sherry Jr. (2003), "Teaching Old Brands New Tricks: Retro Branding and the Revival of Brand Meaning," Journal of Marketing, 67 (July), 19-33.

Campbell, Colin (1987), The Romantic Ethic and the Spirit of Modern Consumerism, New York: Blackwell.

Carr, Edward Hallet (2001), What Is History? New York: Palgrave Macmillan.

Carswell, John (1998), Iznik Pottery, London: British Museum.

Chittick, William C. (2005), Sufism: A Short Introduction, Oxford: Oneworld.

Clunas, Craig (2004), Superfluous Things: Material Culture and Social Status in Early Modern China, Honolulu: University of Hawai'i Press.

Coffey, Amanda and Paul Atkinson (1996), Making Sense of Qualitative Data, Thousand Oaks, CA: Sage.

Cohen, Amnon (2004), “Osmanlı Kudüs'üne Kahvehanelerin Girişi: Edebe Aykırı Bir Yeniliğin Muteber Hale Gelişi," Toplumsal Tarih, 126 (Haziran), 58-64.

Cohen, Lizabeth (2003), A Consumers' Republic: The Politics of Mass Consumption in Postwar America, New York: Knopf.

Cotte, June (1997), "Chances, Trances and Lots of Slots: Gambling
Motives and Consumption Experiences," Journal of Leisure Research, 29 (4), 380-406.

Çavuşoğlu, Mehmed (1977), "Zâtî’nin Letâyifi - II," Türk Dili ve Edebiyatı Dergisi, 22, 143-61.

Dağlığlu, Hikmet Turhan (1940), Onaltıncı Asırda Bursa, Bursa: Bursa Halk Evi Matbaası.

Dalsar, Fahri (1960), Bursa'da İpekcilik, İstanbul: Sermet.

Darnton, Robert (2001), The Great Cat Massacre, London: Penguin.

De Certeau, Michel (1988), The Practice of Everyday Life, Berkeley: University of California Press.

De Lemps, Alain Huetz (1999), "Colonial Beverages and the Consumption of Sugar," in Food: A Culinary History from Antiquity to the Present, ed. John-Louis Flandrin and Massimo Montanari, New York: Columbia University Press, 383-93.

Denegri-Knott, Janice, Detlev Zwick, and Jonathan E. Schroeder (2006), "Mapping Consumer Power: An Integrative Framework for Marketing and Consumer Research," European Journal of Marketing, 40 (9/10), 950-71.

De Vries, Jan (2008), The Industrious Revolution, New York: Cambridge University Press.

Düzdağ, Ertuğrul (1998), Şeyhülislam Ebussu'ud Efendi'nin Fetvalarına Göre Kanuni Devrinde Osmanlı Hayatı, İstanbul: Şule.

Eldem, Sedat Hakkı (1984a), Türk Evi. Cilt 1, İstanbul: Türkiye Anıt Çevre Turizm Değerlerini Koruma Vakfi.

__ (1984b), Türk Evi. Cilt 2, İstanbul: Türkiye Anıt Çevre Turizm Değerlerini Koruma Vakfi.

Ellis, Markman (2004), The Coffee House: A Cultural History, London: Weidenfeld \& Nicolson.

Erder, Leila and Suraiyya Faroqhi (1980), "The Development of the Anatolian Urban Network during the Sixteenth Century," Journal of Economic and Social History of the Orient, 23, 267-303.

Erzen, N. Jale (2002), "The Aesthetics of Space in Ottoman Architecture," in Understanding Islamic Architecture, ed. Attilio Petruccioli and Khalil K. Pirani, London: Routledge, 57-64.

Esir, Hasan Ali (2001), "Lâmi ‘̂̂Çelebi'ye İsnat Edilen Bir Eser: Risâle-i Nefsü'l-Emr-i Lâmi ‘̂̂,” İlmî Araştırmalar, 12, 111-20.

Fairchilds, Cissie (1993), "The Production and Marketing of Populuxe Goods in Eighteenth-Century Paris," in Consumption and the World of Goods, ed. John Brewer and Roy Porter, London: Routledge, 228-49.

Faroqhi, Suraiya (1986), "Coffee and Spices: Official Ottoman Reactions to Egyptian Trade in the Later Sixteenth Century," Wiener Zeitschrift fur die Kunde des Morgenlandes, Festschrift Andreas Tietze, 76, 87-93.

- (1997a), "Crisis and Change, 1590-1699," in An Economic and Social History of the Ottoman Empire 1600-1914, Vol. 2, ed. Halil İnalckk and Donald Quataert, Cambridge: Cambridge University Press, 411-635.

- (1997b), Osmanlı Kültürü ve Gündelik Yaşam: Ortaçă̆'dan Yirminci Yüzyıla, İstanbul: Tarih Vakfı.

- (2002), Stories of Ottoman Men and Women, İstanbul: Eren.

- (2004), "Female Costumes in Late Fifteenth Century Bursa," in Ottoman Costumes: From Textile to Identity, ed. Suraiya Faroqhi and Christoph K. Neumann, İstanbul: Eren, 81-92.

(2007), The Ottoman Empire and the World Around It, London: I. B. Tauris.

Firat, A. Fuat and Nikhilesh Dholakia (1998), Consuming People: 
From Political Economy to Theatres of Consumption, London: Routledge.

Firat, A. Fuat and Alladi Venkatesh (1995), "Liberatory Postmodernism and the Reenchantment of Consumption," Journal of Consumer Research, 22 (December), 239-67.

Fisher, Sydney Nettleton (1971), The Middle East: A History, London: Routledge.

Fletcher, F. Joseph Jr. (1985), "Integrative History: Parallels and Interconnections in the Early Modern Period, 1500-1800," Journal of Turkish Studies, 9 (1), 37-58.

Foucault, Michel (1972/1998), The Archaeology of Knowledge and the Discourse on Language, New York: Pantheon.

(1980), Power and Knowledge: Selected Interviews and Other Writings, New York: Pantheon.

(1990), The History of Sexuality: The Use of Pleasure, Vol. 2, New York: Vintage.

(2000), "The Ethics of the Concern of the Self as a Practice of Freedom," in Ethics: Subjectivity and Truth, ed. Paul Rabinow, London: Penguin, 281-301.

Fraser, Nancy (1999), "Rethinking the Public Sphere: A Contribution to the Critique of Actually Existing Democracy," in Habermas and the Public Sphere, ed. Craig Calhoun, Cambridge, MA: MIT Press, 109-42.

Gerber, Haim (1988), Economy and Society in an Ottoman City: Bursa, 1600-1700, Jerusalem: Hebrew University.

Giesler, Markus (2008), "Conflict and Compromise: Drama in Marketplace Evolution," Journal of Consumer Research, 34 (April), 739-53.

Girard, René (1987), Things Hidden since the Foundation of the World, London: Athlone.

Goffman, Daniel (2004), Osmanlı Dünyası ve Avrupa: 1300-1700, İstanbul: Kitap Yayinevi.

Gökyay, Orhan Şaik (1980), Katip Çelebi: Mizanü’l Hak Fi-Ihtiyari'l-Ehakk, İstanbul: Tercüman.

Goulding, Christina, Avi Shankar, Richard Elliott, and Robin Canniford (2009), "The Marketplace Management of Illicit Pleasure," Journal of Consumer Research, 35 (February), 759-71.

Grehan, James (2007), Everyday Life and Consumer Culture in 18th-Century Damascus, Seattle: University of Washington Press.

Gürtuna, Sevgi (1999), Osmanlı Kadın Giysisi, Ankara: Kültür Bakanlığı.

Habermas, Jürgen (1992), The Structural Transformation of the Public Sphere, Cambridge: Polity.

Hamadeh, Shirine (2008), The City's Pleasures: Istanbul in the Eighteenth Century, Seattle: University of Washington Press.

Hattox, Ralph S. (1996), Coffee and Coffeehouses: The Origins of a Social Beverage in the Medieval Near East, Seattle: University of Washington Press.

Hirschman, Elizabeth C. and Morris B. Holbrook (1982), "Hedonic Consumption: Emerging Concepts, Methods, and Propositions," Journal of Marketing, 46 (Summer), 92-101.

Holt, Douglas B. (1995), "How Consumers Consume: A Typology of Consumption Practices," Journal of Consumer Research, 22 (June), 1-16.

- (1998), "Does Cultural Capital Structure American Consumption?" Journal of Consumer Research, 25 (June), 1-25. - (2002), "Why Do Brands Cause Trouble? A Dialectical Theory of Consumer Culture and Branding," Journal of Consumer Research, 29 (June), 70-90.

Holt, Douglas B. and Craig J. Thompson (2004), "Man-of-Action Heroes: The Pursuit of Heroic Masculinity in Everyday Con- sumption," Journal of Consumer Research, 31 (September), 425-40.

İnalcık, Halil (1969), "Capital Formation in the Ottoman Empire," Journal of Economic History, 29 (March), 97-140.

- (1973), The Ottoman Empire: The Classical Age, 1300 - 1600, London: Weidenfeld \& Nicolson.

- (1974), "Turkish Impact on the Development of Modern Europe," in The Ottoman State and Its Place in the World History, ed. Kemal Karpat, Leiden: Brill, 51-60.

- (1977), "Centralization and Decentralization in Ottoman Administration," in Studies in Eighteenth Century Islamic History, ed. Thomas Naff Roger Owen, Carbondale: Southern Illinois University Press, 27-52.

_ (1988), "The Ruznamçe Registers of the Kadiasker of Rumeli," Turcica, 20, 251-75.

_ (1997), An Economic and Social History of the Ottoman Empire, 1300-1600, Vol. 1, ed. Halil İnalcık and Donald Quataert, Cambridge: Cambridge University Press, 1-379.

İpekten, Haluk (1996), Divan Edebiyatında Edebi Muhitler, İstanbul: Milli Eğitim.

İsen, Mustafa (1989), "Divan Şairlerinin Mesleki Konumları," Milli Eğitim, Sayı: 83 (Mart), 35-41.

Jenkins, Keith (2003), Re-thinking History, London: Routledge.

Jenks, Chris (2003), Transgression, London: Routledge.

Jervis, John (1999), Transgressing the Modern: Explorations in the Western Experience of Otherness, Oxford: Blackwell.

Kafadar, Cemal (1994) "The Ottomans and Europe," in Handbook of European History, 1400-1600, Vol. 1, ed. Thomas A. Brady, Leiden: E. J. Brill, 589-636.

- (2007), "Janissaries and Other Riffraff of Ottoman Istanbul: Rebels without a Cause?" in Identity and Identity Formation in the Ottoman World, ed. Baki Tezcan and Karl K. Barbir, Madison: University of Wisconsin Press, 113-34.

Karababa, Eminegül (2006), "Origins of a Consumer Culture in an Early Modern Context: Ottoman Bursa," unpublished dissertation, Department of Management, Faculty of Business Administration, Bilkent University, Ankara 06800.

Kendall, Gavin and Gary Wickham (2003), Using Foucault's Methods, London: Sage.

Kılıç, Filiz (1994), "Meşa'ürü’ş-Şu'ara: İnceleme ve Tenkitli Metin," unpublished dissertation, Faculty of Literature, Gazi University, Ankara, 06500.

Kinberg, Leah (2008), "Paradise," in Encyclopedia of the Qur'an, Vol. 4, ed. Jane Dammen McAuliffe, Brill Online, http://www .brillonline.nl/subscriber/entry?entry $=$ q3_COM-00143.

Kjeldgaard, Dannie and Jacob Ostberg (2007), "Coffee Grounds and the Global Cup: Glocal Consumer Culture in Scandinavia," Consumption Markets and Culture, 10 (June), 175-87.

Klein, Richard (1993), Cigarettes Are Sublime, London: Duke University Press.

Knysh, Alexander D. (2009), "Sufism and the Qur'an," in Encyclopedia of Qur'an, ed. Jane Dammen McAuliffe, Brill Online, http://www.brillonline.nl/subscriber/entry?entry $=$ q3_COM-00196.

Koçu, Reşat Ekrem ed. (1946) İstanbul Ansiklopedisi, Cilt.1, İstanbul: İstanbul.

Kömeçoğlu, Uğur (2005), "The Publicness and Sociabilities of the Ottoman Coffeehouse," The Public, 12 (2), 5-22.

Korkmaz, Gülsüm Ezgi (2004), "Sûrnâmelerde 1582 Şenliği," unpublished masters dissertation, Turkish Literature Department, Faculty of Humanities and Letters, Bilkent University, Ankara, 06800.

Kozinets, Robert V., John F. Sherry Jr., Diana Storm, Adam Du- 
hachek, Krittinee Nuttavuthisit, and Benet Deberry-Spence (2004), "Ludic Agency and Retail Spectacle," Journal of Consumer Research, 31 (December), 658-72.

Kunt, Metin (1983), The Sultan's Servants: The Transformation of Ottoman Provincial Government, 1550-1650, New York: Columbia University Press.

Kurt, Yılmaz (1996), Osmanlıca Dersleri, Cilt.1, Ankara: Akçağ. Kütükoğlu, Mübahat (1983), Osmanlılarda Narh Müessesesi ve 1640 Tarihli Narh Defteri, İstanbul: Enderun.

Lears, T. J. Jackson (1983), "From Salvation to Self-Realization," in The Culture of Consumption, ed. Richard Wightman Fox and T. J. Jackson Lears, New York: Pantheon, 1-38.

Maclaran, Pauline and Stephen Brown (2005), "The Center Cannot Hold: Consuming the Utopian Marketplace," Journal of Consumer Research, 32 (December), 311-23.

MacLean, Gerald (2005), "Introduction: Re-orienting the Renaissance," in Re-orienting the Renaissance: Cultural Exchanges with the East, ed. Gerald MacLean, New York: Palgrave Macmillan, 1-28.

- (2007), Looking East: English Writing and the Ottoman Empire before 1800, New York: Palgrave Macmillan.

McCracken, Grant David (1988), Culture and Consumption: New Approaches to the Symbolic Character of Consumer Goods and Activities, Bloomington: Indiana University Press.

McKendrick, Neil (1982), "The Consumer Revolution of Eighteenth Century England," in McKendrick et al. 1982, 3-33.

McKendrick, Neil, John Brewer, and John Harold Plumb, eds. (1982), The Birth of a Consumer Society: The Commercialization of Eighteenth-Century England, London: Europa.

Mukerji, Chandra (1983), From Graven Images: Patterns of Modern Materialism, New York: Columbia University Press.

Neumann, Chritoph K. (2004), "How Did a Vizier Dress in the Eighteenth Century?" in Ottoman Costumes: From Textile to Identity, ed. Suraiya Faroqhi and Christoph K. Neumann, Istanbul: Eren, 181-218.

Öcalan, Hasan Basri (2000), Bursa'da Tasavvuf Kültürü (Onyedinci Yüzyll), Bursa: Gaye Kitabevi.

Oldenburg, Ray (1999), The Great Good Place, Philadelphia: Da Capo.

Öztekin, Ali (1996), Gelibolu'lu Mustafa Âlî: Cami'u'l-Buhur Der Mecalis-i Sur, Ankara: Türk Tarih Kurumu.

Öztürk, Hüseyin (1991), Kınalızade Ali Çelebi'de Aile, Ankara: T. C. Başbakanlık Aile Araştırma Kurumu Başkanlığı.

Öztürk, Serdar (2005), "Osmanlı İmparatorluğu'nda Kamusal Alanın Dinamikleri,” İletişim, 21, 95-124.

Pamuk, Şevket (1998), "Ottoman Interventionism in Economic and Monetary Affairs," Revue de Histoire Maghrebine, 25 (91/92), 361-67.

- (1999), Osmanlı İmparatorluğu'nda Paranın Tarihi, İstanbul: Tarih Vakfi.

- (2004), "Institutional Change and the Longevity of the Ottoman Empire, 1500-1800," Journal of Interdisciplinary History, 35 (Autumn), 225-47.

Panofsky, Erwin (1993), Perspective as Symbolic Form, New York: Zone.

Peñaloza, Lisa (2000), "The Commodification of the West: Marketers' Production of Culture at a Western Stock Show and Rodeo," Journal of Marketing, 64 (October), 82-109.

Peñaloza, Lisa and Mary C. Gilly (1999), "Marketer Acculturation: The Changer and the Changed," Journal of Marketing, 63 (July), 84-104.

Plumb, John Harold. (1982), "The Commercialization of Leisure," in McKendrick et al. 1982, 265-85.
Polanyi, Karl (1957), The Great Transformation, Boston: Beacon. Poster, Mark (1989), Critical Theory and Poststructuralism: In Search of a Context, Ithaca, NY: Cornell University Press.

Quataert, Donald (1997), "Clothing Laws, State, and Society in the Ottoman Empire, 1720-1829," International Journal of Middle East Studies, 29 (3), 403-25.

—_ ed. (2000), Consumption Studies and the History of the Ottoman Empire, 1550-1922: An Introduction. New York: SUNY Press.

Rappaport, Erika Diane (2004), Shopping for Pleasure: Women in the Making of London's West End, Princeton, NJ: Princeton University Press.

Reekie, Gail (1993), Temptations: Sex, Selling, and the Department Store, Sydney: Allen \& Unwin.

Ritzer, George (2007), The McDonaldization of Society, Los Angeles: Pine Forge.

Roche, Daniel (2000), A History of Everday Things: The Birth of Consumption in France, 1600-1800, Cambridge: University of Cambridge Press.

Rook, Dennis W. (1985), “The Ritual Dimension of Consumer Behavior," Journal of Consumer Research, 12 (December), 251-64.

Salzman, Ariel (2000), "The Age of Tulips: Confluence and Conflict in Early Modern Consumer Culture, 1550-1730," in Quataert 2000, 83-106.

Sandikci, Özlem and Güliz Ger (2010), "Veiling in Style: How Does a Stigmatized Practice Become Fashionable?" Journal of Consumer Research, 37 (June), 15-36.

Schama, Simon (1987), The Embarrassment of Riches, New York: Knopf.

Schievelbusch, Wolfgang (2000), Keyif Verici Maddelerin Tarihi: Cennet, Tat ve Mantik, Ankara: Dost.

Schroeder, Jonathan E. (2006), "Critical Visual Analysis," in Handbook of Qualitative Research Methods in Marketing, ed. Russell W. Belk, Northampton, MA: Edward Elgar, 303-21.

Schweigger, Salomon (2004), Sultanlar Kentine Yolculuk, 1578-1582, İstanbul: Kitap.

Şeker, Mehmet (1997), Gelibolu'lu Mustafa 'Âlî ve Meva 'idü'nnefais fi-kava 'idi'l Mecalis, Ankara: Türk Tarih Kurumu.

Simmel, Georg (1957), "Fashion," American Journal of Sociology, 62 (May), 541-58.

Slater, Don (1997), Consumer Culture and Modernity, Cambridge: Polity.

Smith, Ruth Ann and David S. Lux (1993), "Historical Method in Consumer Research: Developing Causal Explanations of Change," Journal of Consumer Research, 19 (March), 595-610.

Stern, Barbara S. (1989), "Literary Criticism and Consumer Research: Overview and Illustrative Analysis," Journal of Consumer Research, 16 (December), 322-34.

Taylor, Roderick (1993), Ottoman Embroidery, London: Studio Vista.

Tezcan, Hülya (2004), "Furs and Skins Owned by the Sultans," in Ottoman Costumes: From Textile to Identity, ed. Suraiya Faroqhi and Christoph K. Neumann, İstanbul: Eren, 63-80.

Thévenot, Jean (1978), 1655-1656’da Türkiye, İstanbul: Tercüman.

Thompson, Craig J. (2004), "Marketplace Mythologies and Discourses of Power," Journal of Consumer Research, 31 (June), $162-80$.

Thompson, Craig J. and Zeynep Arsel (2004), "The Starbucks Brandscape and Consumers' (Anticorporate) Experiences of 
Glocalization," Journal of Consumer Research, 31 (December), 631-42.

Thompson, Craig J. and Diana L. Haytko (1997), "Speaking of Fashion: Consumers' Uses of Fashion Discourses and the Appropriation of Countervailing Cultural Meanings," Journal of Consumer Research, 24 (June), 15-42.

Tiger, Lionel (2005), Pursuit of Pleasure, London: Transaction.

Tosh, John (2006), The Pursuit of History: Aims, Methods and New Directions in the Study of Modern History, London: Pearson Education.

Trentmann, Frank (2006), "The Modern Genealogy of the Consumer: Meanings, Identities, and Political Synapses," in Consuming Cultures, Global Prespectives: Historical Trajectories, Transnational Exchanges, ed. John Brewer and Frank Trentmann, Oxford: Berg, 19-70.

Tucker, Kenneth H. (1993), "Aesthetics, Play and Cultural Memory: Giddens and Habermas on the Postmodern Challenge," Sociological Theory, 11 (2), 194-211.

Ülgener, F. Sabri (1981), İktisadi Çözülmenin Ahlak ve Zihniyet Dünyası, İstanbul: Der.

Ünver, Süheyl (1963), “Türkiye'de Kahve ve Kahvehaneler,” Türk Etnografya Dergisi, 5, 39-83.

Urry, John (2000), Consuming Places, London: Routledge.

Veblen, Thorstein (1899/1994), The Theory of the Leisure Class, New York: Dover.

Venkatesh, Alladi (1995), "Ethnoconsumerism: A New Paradigm to Study Cultural and Cross-Cultural Consumer Behavior," in
Marketing in a Multicultural World, ed. Janeen A. Costa and Gary Bamossy, Thousand Oaks, CA: Sage, 26-67.

Vickery, Amanda (1993), "Women and the World of Goods: A Lancashire Consumer and Her Possessions, 1751-81," in Consumption and the World of Goods, ed. John Brewer and Roy Porter, New York: Routledge, 274-304.

Walkowitz, Judith R. (1992), City of Dreadful Delight: Narratives of Sexual Danger in Late-Victorian London, Chicago: University of Chicago Press.

Wang, Di (2000), "The Idle and the Busy: Teahouses and Public Life in Early Twentieth Century Chengdu," Journal of Urban History, 26 (May), 411-37.

Weinberg, Alan Bennett and Bonnie K. Bealer (2002), The World of Caffeine: The Science and Culture of the World's Most Popular Drug, New York: Routledge.

Wills, John E., Jr. (1993), "European Consumption and Asia Production in the Seventeenth and Eighteenth Centuries," in Brewer and Porter 1993, 133-47.

Yazıc1, Tahsin (2009), "Qalandariyya," in Encyclopaedia of Islam, ed. Peri Bearman, Thierry Bianquis, Clifford Edmund Bosworth, Emeri van Donzel and Wolfhart P. Heinrichs, Brill Online, http://www.brillonline.nl/subscriber/entry?entry $=$ islam_COM-0422.

Zilfi, Madeline C. (2004), "Whose Laws? Gendering the Ottoman Sumptuary Regime," in Ottoman Costumes: From Textile to Identity, ed. Suraiya Faroqhi and Christoph K. Neumann, Istanbul: Eren, 125-41. 